\title{
Fibroblastic reticular cells predict response to immune checkpoint inhibitors
}

\author{
Daniele Biasci $^{1,2, \bowtie}$, James Thaventhiran ${ }^{1,2^{*}}$, and Simon Tavaré ${ }^{2,3, *}$ \\ ${ }^{1}$ MRC Toxicology Unit, University of Cambridge, Robinson Way, Cambridge, CB2 ORE, United Kingdom \\ ${ }^{2}$ Cancer Research UK Cambridge Institute, Robinson Way, Cambridge CB2 ORE, United Kingdom \\ ${ }^{3}$ Herbert and Florence Irving Institute for Cancer Dynamics, Columbia University, Schermerhorn Hall, Suite 601, 1190 Amsterdam Ave, New York, NY 10027, United States
}

\begin{abstract}
While the role of CD8+ $\mathbf{T}$ cells in mediating response to cancer 47 immunotherapy is well established, the role of $\mathbf{B}$ cells remains 48 more controversial (1-3). By conducting a large gene expression study of response to immune checkpoint inhibitors (ICI), we show that pre-treatment expression of $B$ cell genes is associated with ICI response independently of CD8+ T cells. However, we discovered that such association can be completely explained by a single gene (FDCSP) expressed outside of the $\mathrm{B}$ cell compartment, in fibroblastic reticular cells (FRCs), which form the reticular network that facilitates interactions between $B$ cells, ${ }^{55}$ $T$ cells and cognate antigens (4-6) and are required to initiate 56 efficient adaptive immune responses in secondary lymphoid or- 57 gans (SLO) and tertiary lymphoid structures (TLS) (4, 7). We 58 validated this finding in three independent cohorts of patients 59 treated with ICI in melanoma and renal cell carcinoma. Taken 60 together, these results suggest that FDCSP is an independent predictor of ICI response, thus opening new avenues to explain the mechanisms of resistance to cancer immunotherapy.
\end{abstract}

Recently, it has been reported that expression of B cell spe- ${ }^{64}$ cific genes inside tumours is associated with response to im- ${ }^{65}$ mune checkpoint inhibitors (ICI), thus suggesting an unap- ${ }^{66}$ preciated biological role for B cells in promoting ICI re- ${ }^{67}$ sponse (8). However, association between B cell gene expres- ${ }^{68}$ sion and ICI response was not statistically significant when ${ }^{69}$ other immune populations, including CD8+ $\mathrm{T}$ cells, were ${ }^{70}$ taken into account (8). For this reason, it remains unclear ${ }^{71}$ whether B cells are associated with ICI response indepen- ${ }^{72}$ dently of CD8+ T cells. Clarifying this point is crucial for ${ }^{73}$ the biological interpretation of these results. In fact, expres- ${ }^{74}$ sion of B cell specific genes in the tumour microenvironment ${ }^{75}$ (TME) is often strongly correlated with markers of CD8+ ${ }^{76}$ cells (9), which express the actual molecular targets of ICI ${ }^{77}$ treatment and are a validated predictor of immunotherapy re- ${ }^{78}$ sponse (10-12). Two additional recent studies on this topic ${ }^{79}$ did not address the issue, because they described predictive ${ }^{80}$ signatures containing both $\mathrm{B}$ cell and CD8+ T cell mark- ${ }^{81}$ ers, as well as genes expressed in other immune cell types ${ }^{82}$ $(13,14)$. In order to address this problem, we analysed the ${ }^{83}$ entire transcriptome of a larger number of melanoma samples ${ }^{84}$ compared to previous studies $(n=366)$, and we then con- ${ }^{85}$ sidered only samples collected before commencing treatment ${ }^{86}$ with immune checkpoint inhibitors. Moreover, we excluded ${ }^{87}$ tumour samples obtained from lymph node metastasis, in or- ${ }^{88}$ der to minimise the risk of capturing unrelated immune popu- ${ }^{89}$ lations from the adjacent lymphoid tissue (see supplementary ${ }^{90}$ methods). We calculated the correlation between expression ${ }^{91}$

* These authors have contributed equally to this work. of each gene at baseline and subsequent treatment response, as defined in the original studies according to the RECIST criteria (15). A distinct group of genes showed significant association with treatment response, namely: CR2 (CD21), MS4A1 (CD20), CD19, FCER2 (CD23), PAX5, BANK1, VPREB3, TCL1A, CLEC17A and FDCSP (Fig. 1A and Table $\mathrm{S} 1)$. Literature reports that these genes are predominantly expressed in B cells (16), with the exception of FDCSP, which was found to be expressed follicular dendritic cells (FDCs) isolated from secondary lymphoid organs, but not in B cells $(17,18)$. In order to identify the cell populations expressing these genes in tumours, we assessed their expression in single-cell RNA sequencing data (scRNAseq) from human cancer samples (19). First, we confirmed that genes identified by our association study were specifically expressed in tumour-associated B cells (Fig. S7). Second, we observed that FDCSP was not expressed in tumour-associated B cells (Fig. S1), but identified a subset of fibroblastic cells $(F A P+C O L 1 A 1+C D 31-;$ Fig. S2) expressing markers consistent with FRC identity (CCL19+CCL21+BAFF+; 4, 5; Figures 2 and S3 and tables S5 and S6). Finally, we confirmed these results in an independent set of melanoma samples profiled at the single-cell level (20; Figures 2, S4 to S6 and S8). We then sought to determine whether expression of these genes was associated with ICI response independently of CD8+ $\mathrm{T}$ cell infiltration. To this aim, we repeated the association analysis after taking into account expression markers of T cells, NK cells, cross-presenting dendritic cells (21) and interferon-gamma response (22; Fig. 1D and table S2). We found that only four genes were associated with ICI response independently of all immune markers considered: MS4A1 (prototypical B cell marker), CLEC17A (expressed in dividing B cells in germinal centers; 23), $C R 2$ (expressed in mature B cells and FDCs; 24) and FDCSP (expressed in FRCs but not in B cells). This result suggested that presence of B cells and FRCs in the tumour microenvironment (TME) before treatment was associated with subsequent ICI response independently of CD8+ T cells (Fig. 1D and Table S7). Remarkably, we observed that FDCSP remained significantly associated with ICI response even after B cell markers were taken into account (Fig. 1D) and that no other gene remained significant after FDCSP expression was included in the model (Fig. 1D). Taken together, these results suggest that expression of FDCSP might be an independent predictor of ICI response. We tested this hypothesis in a completely independent cohort of melanoma patients treated with anti-PD1, either alone or in combination with anti-CTLA4 
bioRxiv preprint doi: https://doi.org/10.1101/2020.02.19.955666; this version posted February 28, 2020. The copyright holder for this preprint (which was not certified by peer review) is the author/funder, who has granted bioRxiv a license to display the preprint in perpetuity. It is made available under aCC-BY-ND 4.0 International license.

(25). In this validation cohort, patients with higher expres- 151 sion of FDCSP at baseline experienced significantly longer ${ }_{152}$ overall survival (log-rank $p<0.0001)$ and progression-free ${ }_{153}$ survival (log-rank $p<0.0001)$ after commencing treatment 154 with ICI (Figures 1B and 1C). Moreover, we observed a sig- 155 nificant association between expression of FDCSP at base- 156 line and subsequent RECIST response (Cochran-Armitage ${ }_{157}$ test $p<0.0001$; Fig. 1E). We sought to replicate this ob- ${ }_{158}$ servation in two additional independent cohorts of patients 159 treated with ICI in melanoma (8) and clear cell renal cell car- 160 cinoma (26) and found similar results (Figures $1 \mathrm{~F}$ and $1 \mathrm{G}$ ). On the other hand, testing B cell markers in the validation $\mathrm{CO}^{-}{ }_{16}$ horts produced less consistent results (Fig. S9). Finally, we performed multiple linear regression analysis and found that ${ }_{163}^{162}$ the association between FDCSP and ICI response was inde- 164 pendent of CD8+ T cells, CD4+ T cells, B cells, NK cells, ${ }_{166}{ }_{165}$ myeloid Dendritic cells (mDCs), Macrophages and Plasma ${ }^{167}$ cells (Tables 1 and S3). While CD8+ T cells express the ${ }_{169}^{168}$ molecular targets of ICI, and their presence in the TME is ${ }^{170}$ a validated predictor of ICI response (10-12), the role of $B_{172}{ }_{171}^{17}$ cells remains more controversial (1-3). Because $\mathrm{T}$ and $\mathrm{B} 173$ cells often co-occur in the TME (27), gene expression stud- ${ }_{175}^{174}$ ies consistently reported strong correlation between $\mathrm{T}$ cells, ${ }^{176}$ $\mathrm{B}$ cells and other immune cell types, especially in melanoma ${ }_{178}^{177}$ (9). As a consequence, assessing whether B cells are asso- 179 ciated with ICI response independently of CD8+ T cells has ${ }_{181}^{180}$ been proven challenging (8). By analysing a larger number ${ }^{182}$ of samples compared to previous studies, we were able to ${ }_{184}^{183}$ demonstrate that B cells predict ICI response independently 185 of CD8+ T cells (Fig. 1D and Table S4). This supports the ${ }_{187}^{186}$ idea that B cells might actively promote immunotherapy re- 188 sponse (3), rather than being irrelevant or detrimental to it ${ }_{190}^{189}$ $(1,2)$. However, our data also shows that such positive as- 191 sociation can be completely explained by a single gene ex- ${ }_{193}^{192}$ pressed outside of the B cell compartment. We have demon- ${ }^{194}$ strated that FDCSP is transcribed in a subset of fibroblas- ${ }^{195}$ tic cells up-regulating CCL19, CCL2I and BAFF and down- ${ }^{197}$ regulating genes associated with canonical fibroblasts, such ${ }_{190}^{198}$ as extracellular matrix genes (Fig. 2, Table S5, Table S6), an ${ }^{200}$ expression pattern consistent with FRC identity $(4,5)$. One ${ }_{202}^{201}$ way to reconcile these observations is to consider that FRCs 203 are required to initiate efficient $\mathrm{B}$ and $\mathrm{T}$ cell responses (4). ${ }_{205}^{204}$ In both secondary lymphoid organs (SLO) and tertiary lym- 206 phoid structures (TLS), FRCs form reticular networks that fa- ${ }_{208}^{207}$ cilitate interactions between B cells, T cells and their cognate ${ }^{209}$ antigens $(5,6)$. Homing of immune cells into the network ${ }_{211}^{210}$ requires interaction between chemokines produced by FRCs ${ }^{212}$ (CCL19 and CCL21) and their receptor (CCR7) expressed ${ }_{214}^{213}$ on T cells, B cells and dendritic cells $\left(28,29\right.$; see also Table ${ }^{215}$ S1). Accordingly, depleting FRCs causes loss of T cells, $B_{217}^{216}$ cells and dendritic cells in both SLO and TLS and decreases ${ }^{218}$ the magnitude of $\mathrm{B}$ and $\mathrm{T}$ cell responses to subsequent vi- ${ }_{220}^{219}$ ral infection $(4,7)$. Perhaps more importantly, differentiation 221 of fibroblasts into FRCs occurs early during TLS formation, ${ }_{223} 22$ precedes $\mathrm{B}$ and $\mathrm{T}$ cell infiltration and can still be observed ${ }^{224}$ in Rag2-/- mice (7). In this context, our finding that a gene ${ }_{226}^{225}$ expressed in FRCs is associated with ICI response indepen- 227 dently of B and T cell infiltration is coherent with the current understanding of TLS neogenesis. Taken together, these observations suggest that the reported association between B cells and ICI response (8), albeit independent of CD8+ T cells, might ultimately be secondary to the presence of FRCs in the TME. The identification of FDCSP as a single marker of ICI response should enable even larger studies to test this conclusion. To our knowledge, this is the first time that FRCs are directly implicated in ICI response, thus opening new avenues to explain the mechanisms of resistance to ICI.

\section{Bibliography}

1. Shalapour, S. et al. Immunosuppressive plasma cells impede t-cell-dependent immunogenic chemotherapy. Nature 521, 94-98 (2015).

2. Damsky, W. et al. B cell depletion or absence does not impede anti-tumor activity of pd-1 inhibitors. Journal for immunotherapy of cancer 7, 153 (2019).

3. Hollern, D. P. et al. B cells and t follicular helper cells mediate response to checkpoint inhibitors in high mutation burden mouse models of breast cancer. Cell 179, 1191-1206 (2019).

4. Denton, A. E., Roberts, E. W., Linterman, M. A. \& Fearon, D. T. Fibroblastic reticular cells of the lymph node are required for retention of resting but not activated cd8+ $t$ cells. Proceedings of the National Academy of Sciences 111, 12139-12144 (2014).

5. Cremasco, V. et al. B cell homeostasis and follicle confines are governed by fibroblastic reticular cells. Nature immunology 15, 973-981 (2014).

6. Denton, A. E., Carr, E. J., Magiera, L. P., Watts, A. J. \& Fearon, D. T. Embryonic fap+ lymphoid tissue organizer cells generate the reticular network of adult lymph nodes. Journal of Experimental Medicine 216, 2242-2252 (2019).

7. Nayar, S. et al. Immunofibroblasts are pivotal drivers of tertiary lymphoid structure formation and local pathology. Proceedings of the National Academy of Sciences 116, 13490-13497 (2019).

8. Helmink, B. A. et al. B cells and tertiary lymphoid structures promote immunotherapy response. Nature (2020).

9. Iglesia, M. D. et al. Genomic analysis of immune cell infiltrates across 11 tumor types. JNCl: Journal of the National Cancer Institute 108 (2016).

10. Ji, R.-R. et al. An immune-active tumor microenvironment favors clinical response to ipilimumab. Cancer Immunology, Immunotherapy 61, 1019-1031 (2012).

11. Ayers, M. et al. Ifn- $\gamma$-related mrna profile predicts clinical response to pd- 1 blockade. The Journal of clinical investigation 127, 2930-2940 (2017).

12. Cristescu, R. et al. Pan-tumor genomic biomarkers for pd-1 checkpoint blockade-based immunotherapy. Science 362, eaar3593 (2018).

13. Cabrita, R. et al. Tertiary lymphoid structures improve immunotherapy and survival in melanoma. Nature (2020)

14. Petitprez, F. et al. B cells are associated with survival and immunotherapy response in sarcoma. Nature (2020)

15. Schwartz, L. H. et al. Recist 1.1-update and clarification: From the recist committee. European journal of cancer 62, 132-137 (2016).

16. Kassambara, A. et al. Genomicscape: an easy-to-use web tool for gene expression data analysis. application to investigate the molecular events in the differentiation of $b$ cells into plasma cells. PLoS computational biology 11, e1004077 (2015).

17. Marshall, A. J. et al. Fdc-sp, a novel secreted protein expressed by follicular dendritic cells. The Journal of Immunology 169, 2381-2389 (2002).

18. Al-Alwan, M. et al. Follicular dendritic cell secreted protein (fdc-sp) regulates germinal center and antibody responses. The Journal of Immunology 178, 7859-7867 (2007)

19. Zilionis, R. et al. Single-cell transcriptomics of human and mouse lung cancers reveals conserved myeloid populations across individuals and species. Immunity 50, 1317-1334 (2019).

20. Jerby-Arnon, L. et al. A cancer cell program promotes t cell exclusion and resistance to checkpoint blockade. Cell 175, 984-997 (2018).

21. Hartung, E. et al. Induction of potent CD8 $t$ cell cytotoxicity by specific targeting of antigen to cross-presenting dendritic cells in vivo via murine or human XCR1. The Journal of Immunology 194, 1069-1079 (2014).

22. Chow, M. T. et al. Intratumoral activity of the cxcr3 chemokine system is required for the efficacy of anti-pd-1 therapy. Immunity 50, 1498-1512 (2019).

23. Graham, S. A. et al. Prolectin, a glycan-binding receptor on dividing b cells in germinal centers. Journal of Biological Chemistry 284, 18537-18544 (2009).

24. Takahashi, K. et al. Mouse complement receptors type 1 (cr1; cd35) and type 2 (cr2; cd21): expression on normal $b$ cell subpopulations and decreased levels during the development of autoimmunity in $\mathrm{mr} / / \mathrm{pr}$ mice. The Journal of Immunology 159, 1557-1569 (1997).

25. Gide, T. N. et al. Distinct immune cell populations define response to anti-pd-1 monotherapy and anti-pd-1/anti-ctla-4 combined therapy. Cancer cell 35, 238-255 (2019).

26. Miao, D. et al. Genomic correlates of response to immune checkpoint therapies in clear cell renal cell carcinoma. Science 359, 801-806 (2018).

27. Garnelo, M. et al. Interaction between tumour-infiltrating $b$ cells and t cells controls the progression of hepatocellular carcinoma. Gut 66, 342-351 (2017).

28. Gunn, M. D. et al. Mice lacking expression of secondary lymphoid organ chemokine have defects in lymphocyte homing and dendritic cell localization. The Journal of experimental medicine 189, 451-460 (1999).

29. Förster, R. et al. Ccr7 coordinates the primary immune response by establishing functional microenvironments in secondary lymphoid organs. Cell 99, 23-33 (1999). 
bioRxiv preprint doi: https://doi.org/10.1101/2020.02.19.955666; this version posted February 28,2020 . The copyright holder for this preprint (which was not certified by peer review) is the author/funder, who has granted bioRxiv a license to display the preprint in perpetuity. It is made available under aCC-BY-ND 4.0 International license.

(A)

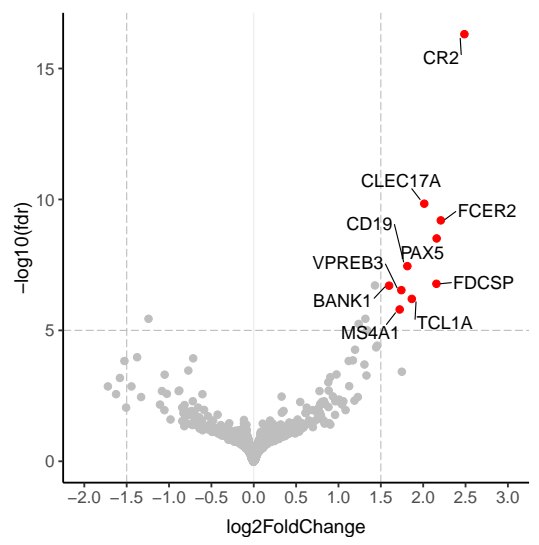

(B)

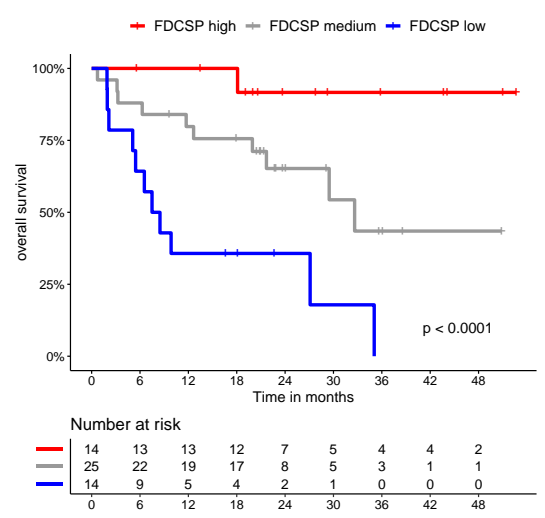

(C)

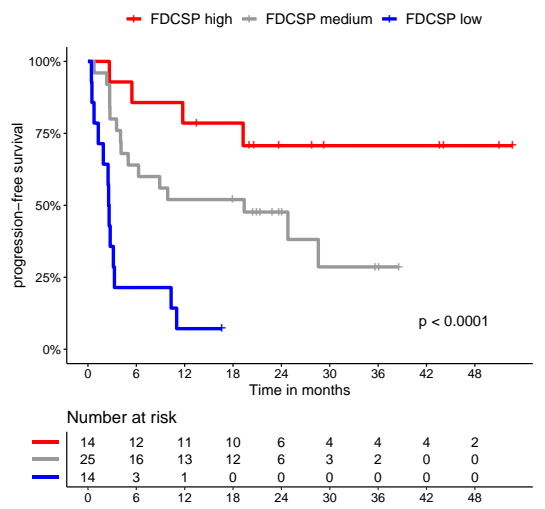

(D)

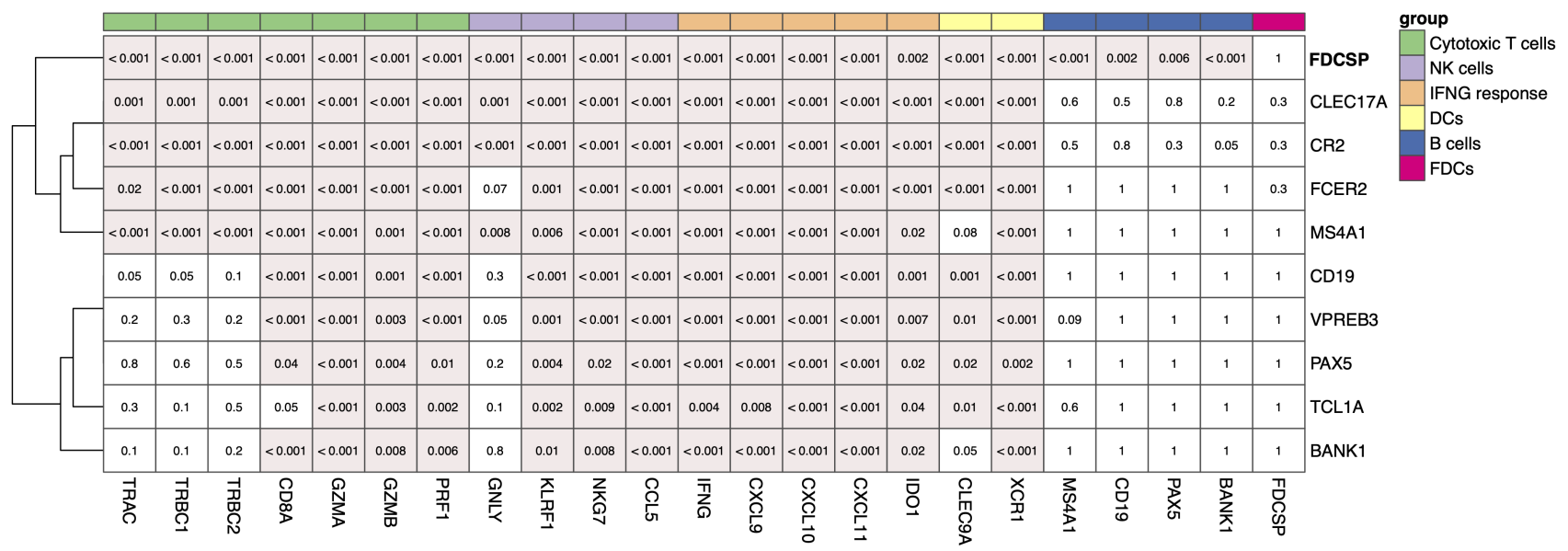

(E)

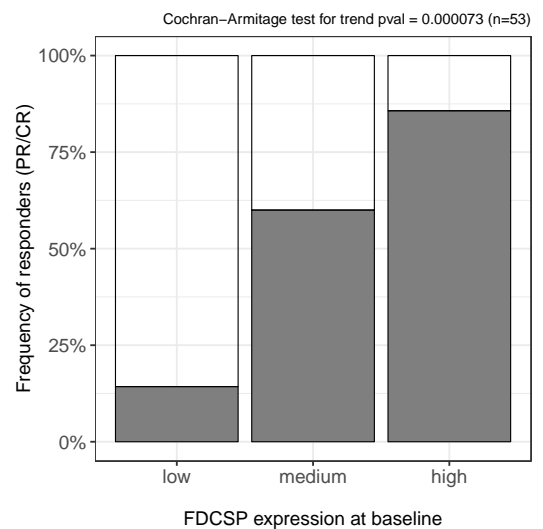

(F)

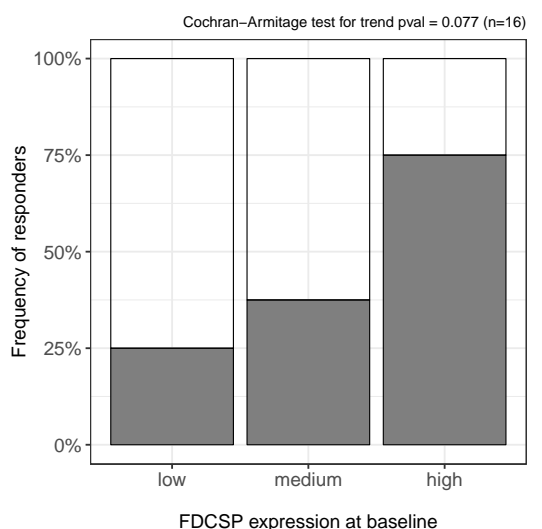

(G)

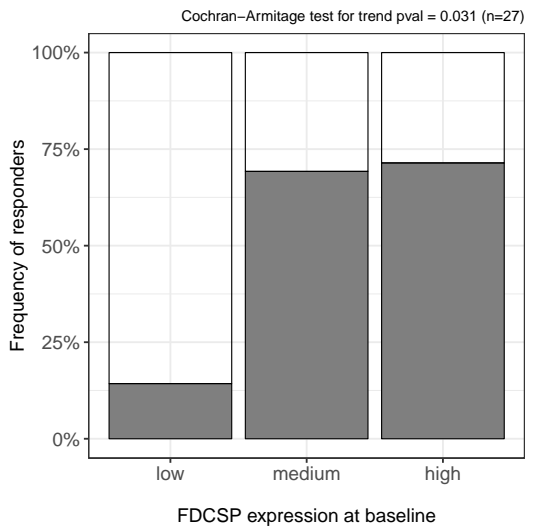

Fig. 1. Expression of FDCSP is an independent predictor of response to immune checkpoint inhibitors. A. Volcano plot showing genes significantly associated with response to ICI. B-C Kaplan-Meier curves showing different overall survival and progression-free survival in melanoma patients after commencing treatment with ICI. Patients from the first validation cohort (25; see supplementary methods) were stratified in three groups according to pre-treatment expression of FDCSP. D Heatmap showing association between pre-treatment expression of B cell or FRC genes (rows) and subsequent ICl response after the effect of other immune markers (columns) was taken into account. The number inside each cell represents the Wald test $\mathrm{p}$-value for the underlying effect size estimate obtained using the negative binomial model for RNAseq counts implemented in DESEq2 (see supplementary methods). Nominal p-values were corrected for multiple testing using Benjamini-Yekutieli false discovery rate (FDR) and are also reported in Table S7. A red background highlights effect sizes estimated to be greater than zero with FDR $<0.05$. In this study, an effect size greater than zero represents a positive association between gene expression and probability of ICI response. E-G Association between pre-treatment expression of $F D C S P$ and subsequent $\mathrm{ICI}$ response in the first (25), second (8) and third validation cohort (26). See supplementary methods. 
bioRxiv preprint doi: https://doi.org/10.1101/2020.02.19.955666; this version posted February 28, 2020. The copyright holder for this preprint (which was not certified by peer review) is the author/funder, who has granted bioRxiv a license to display the preprint in perpetuity. It is made available under aCC-BY-ND 4.0 International license.

Table 1 | Multiple linear regression analysis of ICI response. Expression values of cell type specific markers were summarised by calculating their geometric mean. The resulting summarised values were used as independent variables in a multiple linear regression model aimed at explaining ICI response. The table reports the regression coefficient estimates obtained by fitting the model to all pre-treatment melanoma samples available for this study (see Supplementary methods). The probability of observing estimates different from zero merely by chance was calculated by leveraging on the null distribution of the t-test statistic $(\operatorname{Pr}(>|t|))$. The results show that expression of $F D C S P$ is significantly associated with ICI response independently of genes expressed in major immune cell types. Asterisks indicate the level of statistical significance: ${ }^{* \star *}$ indicates $p$-value $\leq 0.001,{ }^{* *}$ indicates $p$-value $\leq 0.01,{ }^{*}$ indicates $p$-value $\leq 0.05$.

\begin{tabular}{lllrrrrr}
\hline & Cell type & Markers & Estimate & Std. Error & $\mathrm{t}$ value & $\operatorname{Pr}(>|\mathrm{t}|)$ \\
\hline 1 & CD8+ T cells & CD8A, CD8B, TRAC & 0.032 & 0.078 & 0.40 & 0.69 & \\
2 & CD4+ T cells & CD4, TRAC & 0.057 & 0.110 & 0.52 & 0.60 & \\
3 & NK cells & -0.089 & 0.092 & -0.96 & 0.34 & \\
4 & B cells & GNLY, KLRF1 & 0.044 & 0.049 & 0.90 & 0.37 & \\
5 & Macrophages & CD163, MARCO & -0.014 & 0.049 & -0.29 & 0.77 & \\
6 & Dendritic cells & CD1A, CD1B, CD1E, LILRA4 & -0.053 & 0.075 & -0.70 & 0.48 & \\
7 & FDCSP+ cells & FDCSP & 0.071 & 0.027 & 2.60 & 0.0092 & $* *$ \\
\hline
\end{tabular}


bioRxiv preprint doi: https://doi.org/10.1101/2020.02.19.955666; this version posted February 28, 2020. The copyright holder for this preprint (which was not certified by peer review) is the author/funder, who has granted bioRxiv a license to display the preprint in perpetuity. It is made available under aCC-BY-ND 4.0 International license.

(A)

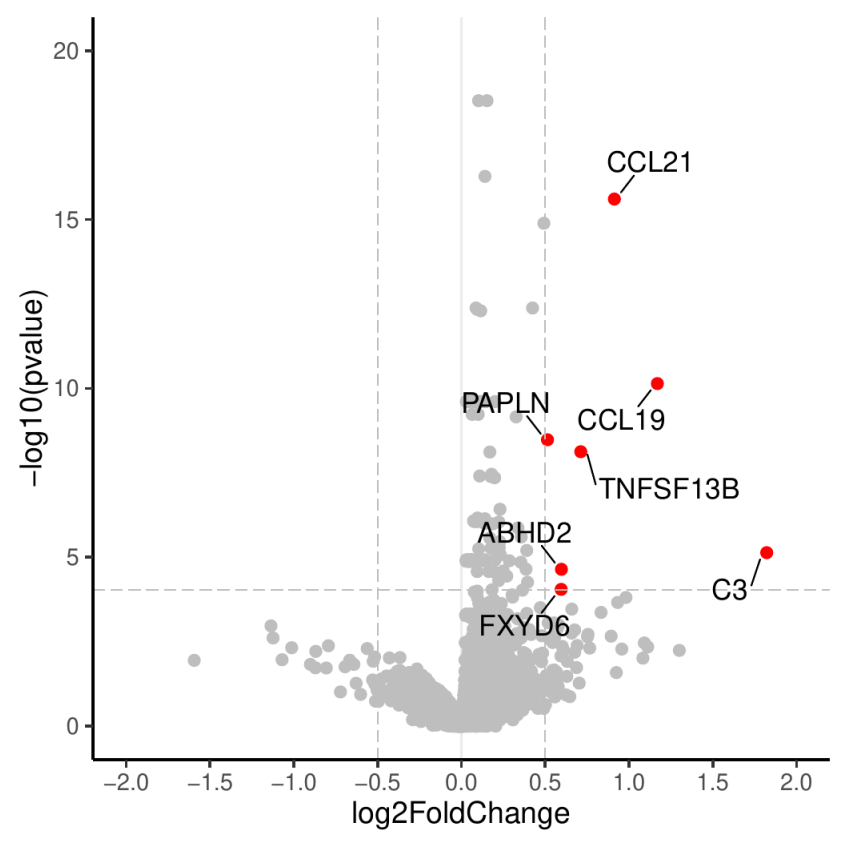

(B)

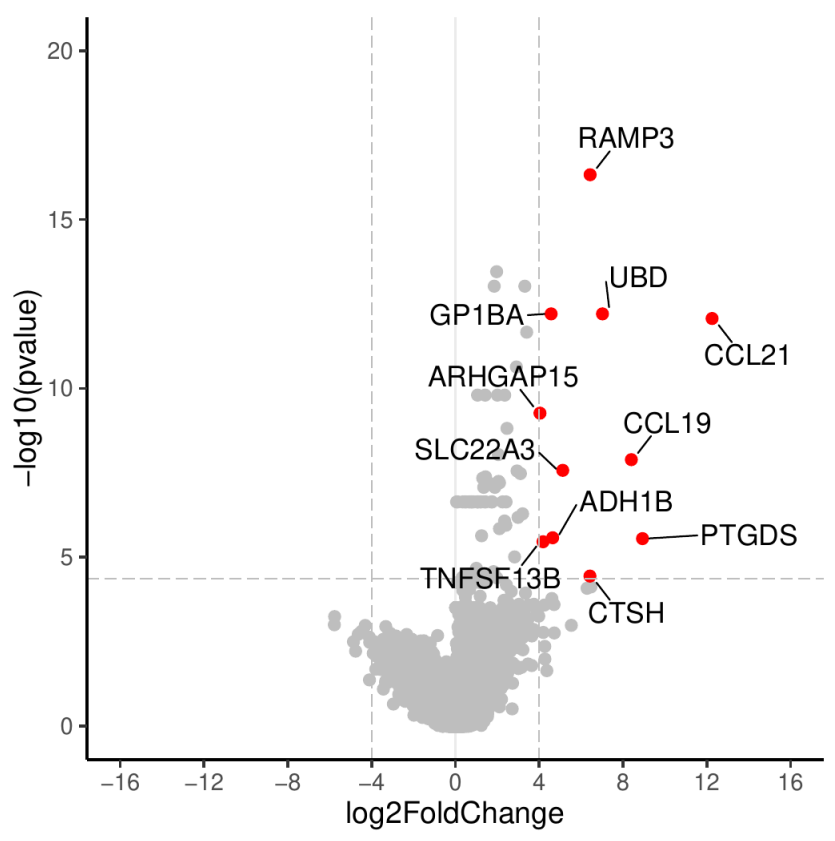

(C)
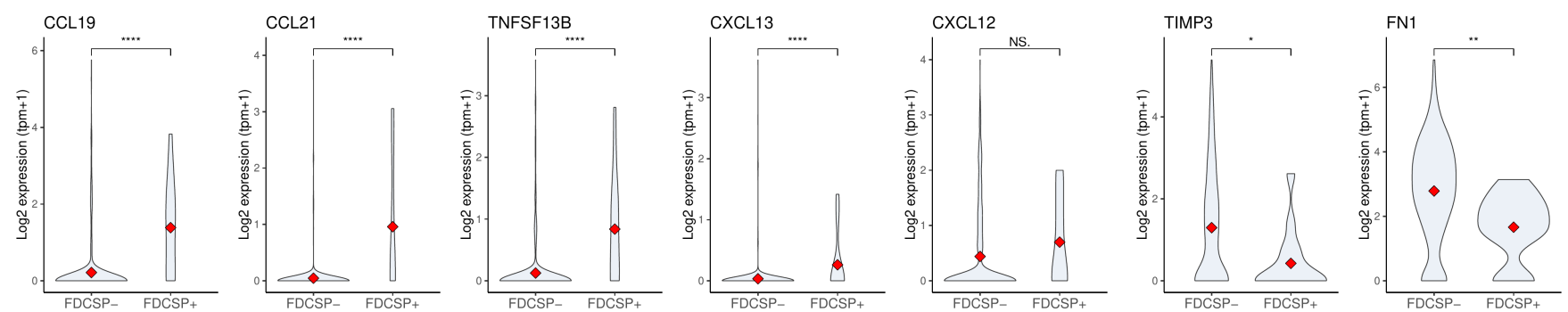

(D)
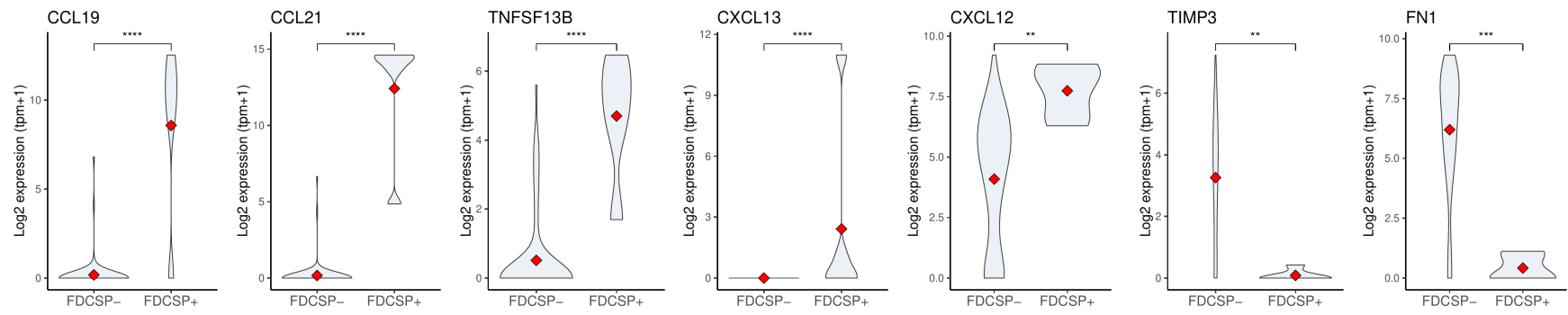

Fig. 2. FDCSP+ fibroblasts upregulate FRCs markers in lung cancer and melanoma. Differential gene expression analysis comparing single-cell transcriptomes of $F D C S P+$ fibroblasts versus FDCSP-fibroblasts obtained from lung cancer and melanoma tumours. The analysis was performed using gene expression data published in $(19,20)$; see also supplementary methods, Table S5 and Table S6. A. Volcano plot representing genes differentially expressed between $F D C S P+$ and $F D C S P$ - fibroblasts shows that FDCSP+ fibroblasts significantly upregulate expression of FRCs markers (CCL19, CCL21, TNFSF13B/BAFF) in lung cancer. Genes considered significantly up-regulated $\left(\log _{2}(f c)>\max \left(\log _{2}(f c)\right) / 4\right.$ and FDR $\left.<0.05\right)$ are marked in red; dotted lines represent chosen $\log _{2}(f c)$ and FDR cutoffs. B. Volcano plot representing genes differentially expressed between FDCSP+ and FDCSP-fibroblasts and confirming significant up-regulation of FRCs markers in melanoma. C. Violin plots comparing distribution of gene expression values in FDCSP+ and FDCSP- fibroblasts in lung cancer. The plots shows that $F D C S P+$ fibroblasts significantly upregulate cytokines relevant to FRCs function while down-regulating genes involved in secretion of the extracellular matrix (TIMP3, FN1). Statistical significance was assessed using unpaired two-samples Wilcoxon test. A red diamond represents the median value of each distribution. D. Comparing FDCSP+ and FDCSP- obtained from melanoma tumours leads to similar results (see panel C). 


\section{Appendix S1: supplementary methods}

Bulk RNAseq: discovery cohorts. The RNAseq datasets used in this study as discovery cohorts were downloaded from the following published sources: data for 27 melanoma samples from patients that went on to receive ICI treatment was downloaded from the NIH Genomics Data Common Portal, study TCGA-SKCM $(1,2)$; data for 42 pre-ICI melanoma samples was downloaded from dbGaP (3), study phs000452.v2.p1 (4); data for 109 melanoma samples collected before or during ICI treatment was downloaded from Gene Expression Omnibus (GEO; 5), series GSE91061 (6); data for 28 melanoma samples collected before ICI treatment was downloaded from GEO, series GSE78220 (7); data for 37 melanoma samples collected before or during ICI treatment was downloaded from GEO, series GSE115821 (8). Clinical annotations for each sample (i.e. type of ICI treatment received, sample collection time point, tumour site, treatment response) were obtained from the original publications. Samples collected after commencing treatment with ICI, samples obtained from lymph node metastasis, and samples for which treatment response status was not available were excluded from subsequent analyses, leaving 137 pretreatment samples available for this study. This manuscript reanalyses data from already published studies: ethics and consent information can be found in the original studies.

Bulk RNAseq: validation cohorts. The RNAseq datasets used in this study as validation cohorts were downloaded from the following published sources. First validation cohort: data for 91 melanoma samples collected before or during ICI treatment was downloaded from the European Nucleotide Archive (ENA; 9), study PRJEB23709 (10). Second validation cohort: data for 16 melanoma samples collected before ICI treatment was obtained from (11). Third validation cohort: data for 33 clear cell renal cell carcinoma samples collected before ICI treatment was obtained from (12). Clinical annotations for each sample were obtained from the original publications. Samples collected after commencing treatment with ICI and samples for which treatment response status was not available were excluded from subsequent analyses.

Bulk RNAseq: gene expression quantification. Sequences of all known human transcripts were downloaded from Ensembl release 97 (13). Transcript quantification was performed using Kallisto ver. 0.43 (14) and gene-level count matrices for use in DESeq2 (15) were calculated using tximport (16) as recommended by DESeq2 authors (17). All subsequent analyses on gene expression were performed using R 3.5.0 (18). For differential expression analysis, raw counts were used directly in DESeq2 as recommended (17). For other downstream analyses (i.e. survival curves, multiple correlation analysis and others) counts data were transformed using the variance stabilizing transformation (19) as implemented in DESEq2 (17) and potential systematic differences between cohorts were corrected using ComBat (20) as implemented in the sva package (21). The methods described in this section were used to quantify gene expression in all datasets used in this study as discovery cohorts and for the first validation cohort, for which original FASTQ files were available. For the second and third validation cohort (10), we used the gene expression values provided in the original publications $(11,12)$.

Bulk RNAseq: genes associated with ICI response. In the discovery cohorts, association between gene expression and ICI response was calculated using the DESeq2 model based on the negative binomial distribution (15). Raw counts for each gene were used directly in the model as recommended by DESeq2 authors (17). We used the ICI response status for each patient as reported in the original study $(1,4,6-8)$ according to the RECIST criteria (22). RECIST response categories were encoded as a numerical score as follows: PD (progressive disease) $=-1$, SD (stable disease) $=0, \mathrm{PR}$ (partial response) $=0.5, \mathrm{CR}$ (complete response) $=1$. When we assessed the use of a different numerical score (i.e. $\mathrm{PD}=0, \mathrm{SD}=0.33, \mathrm{PR}=0.66, \mathrm{CR}=1$ ), we obtained similar results. In order to account for systematic differences between cohorts, a categorical variable encoding the cohort of origin for each sample was included as a covariate in the DESeq2 association model. In order to take into account the effect of known immune markers (Fig. 1D), the association analysis was repeated after their expression level was calculated according to DESeq2 documentation (17) and added to the model as an additional covariate.

Bulk RNAseq: survival curves. Survival curves were plotted using the R package survminer (23). Patients were stratified in three groups according to the baseline expression of the gene of interest: the high expression group was defined as containing the $25 \%$ of samples with highest expression, the low expression group was defined as containing the $25 \%$ of samples with lowest expression, and the medium expression group was defined as containing the remaining samples. Statistical significance of the observed difference between groups was assessed using the Logrank test (24).

Single-cell RNAseq: original data sets. Expression values (normalised counts) for 54773 single cells isolated from nonsmall-cell lung cancer (NSCLC) tumour samples were downloaded from GEO, series GSE127465 (25). Cell type annotation and a two-dimensional visualisation (SPRING plot, 26) of single-cell transcriptomes were also obtained from the original publication (25) and used for subsequent analyses. Expression values (transcripts per million) for 7186 single cells isolated from melanoma samples were downloaded from GEO, series GSE115978 (27). Cell type annotation and a two-dimensional visualisation (tSNE plot, 28) of single-cell transcriptomes were obtained from the original publication (27) and used for subsequent analyses. 
bioRxiv preprint doi: https://doi.org/10.1101/2020.02.19.955666; this version posted February 28, 2020. The copyright holder for this preprint (which was not certified by peer review) is the author/funder, who has granted bioRxiv a license to display the preprint in perpetuity. It is made available under aCC-BY-ND 4.0 International license.

Single-cell RNAseq: differentially expressed genes. Expression values obtained from GSE127465 and GSE115978 were transformed in logarithmic scale $\left(y=\log _{2}(x+1)\right)$. Cells annotated as fibroblasts in the original study were selected and used to compare fibroblasts expressing FDCSP (FDCSP+) against fibroblasts not expressing FDCSP (FDCSP-). Statistical significance for gene expression differences observed between these two groups was assessed using unpaired two-samples Wilcoxon test (29). Genes were ranked using a numerical score which takes into account both p-value and $\log _{2}(f c)$ : score $=\sqrt{-\log _{10}(\mathrm{p}-\text { value }) *\left|\log _{2}(f c)\right|} * \operatorname{sign}\left(\log _{2}(f c)\right)$. Results for GSE127465 (non-small cell lung cancer) and GSE115978 (melanoma) were meta-analysed using the RankProduct method $(30,31)$ and are presented in Tables S5 and S6.

Code availability. The authors declare that the code used for this study is available upon request.

\section{Supplementary methods references.}

1. Akbani, R. et al. Genomic classification of cutaneous melanoma. Cell 161, 1681-1696 (2015).

2. Grossman, R. L. et al. Toward a shared vision for cancer genomic data. New England Journal of Medicine 375, 1109-1112 (2016).

3. Mailman, M. D. et al. The ncbi dbgap database of genotypes and phenotypes. Nature genetics 39, 1181-1186 (2007).

4. Van Allen, E. M. et al. Genomic correlates of response to ctla-4 blockade in metastatic melanoma. Science 350, 207-211 (2015).

5. Edgar, R., Domrachev, M. \& Lash, A. E. Gene expression omnibus: Ncbi gene expression and hybridization array data repository. Nucleic acids research 30, 207-210 (2002).

6. Riaz, N. et al. Tumor and microenvironment evolution during immunotherapy with nivolumab. Cell 171, 934-949 (2017).

7. Hugo, W. et al. Genomic and transcriptomic features of response to anti-pd-1 therapy in metastatic melanoma. Cell 165, 35-44 (2016).

8. Auslander, N. et al. Robust prediction of response to immune checkpoint blockade therapy in metastatic melanoma. Nature medicine 24, 1545-1549 (2018).

9. Leinonen, R. et al. The european nucleotide archive. Nucleic acids research 39, D28-D31 (2010).

10. Gide, T. N. et al. Distinct immune cell populations define response to anti-pd-1 monotherapy and anti-pd-1/anti-ctla-4 combined therapy. Cancer cell 35, 238-255 (2019).

11. Helmink, B. A. et al. B cells and tertiary lymphoid structures promote immunotherapy response. Nature (2020).

12. Miao, D. et al. Genomic correlates of response to immune checkpoint therapies in clear cell renal cell carcinoma. Science 359, 801-806 (2018).

13. Cunningham, F. et al. Ensembl 2019. Nucleic Acids Research 47, D745-D751 (2018). URL https://doi.org/10.1093/nar/gky1113.

14. Bray, N. L., Pimentel, H., Melsted, P. \& Pachter, L. Near-optimal probabilistic RNA-seq quantification. Nature Biotechnology 34, 525-527 (2016). URL https: //doi . org/10 . 1038/nbt. 3519.

15. Love, M. I., Huber, W. \& Anders, S. Moderated estimation of fold change and dispersion for RNA-seq data with DESeq2. Genome Biology 15 (2014). URL https://doi.org/10.1186/ s13059-014-0550-8.

16. Soneson, C., Love, M. I. \& Robinson, M. D. Differential analyses for RNA-seq: transcript-level estimates improve gene-level inferences. F1000Research 4, 1521 (2015). URL https://doi. org/10.12688/f1000research.7563.1.

17. Love, M. I., Anders, S. \& Huber, W. Analyzing rna-seq data with deseq2 (2019). URL http://bioconductor.org/packages/devel/bioc/vignettes/DESeq2/inst/doc/DESeq2 . html\#tximport.

18. R Core Team. R: A Language and Environment for Statistical Computing. R Foundation for Statistical Computing, Vienna, Austria (2018). URL https: //www. R-project. org/.

19. Huber, W., von Heydebreck, A., Sültmann, H., Poustka, A. \& Vingron, M. Parameter estimation for the calibration and variance stabilization of microarray data. Statistical applications in genetics and molecular biology 2 (2003).

20. Johnson, W. E., Li, C. \& Rabinovic, A. Adjusting batch effects in microarray expression data using empirical bayes methods. Biostatistics 8, 118-127 (2007).

21. Leek, J. T. et al. Sva: surrogate variable analysis. 2015. R package version $\mathbf{3}, 25-27$.

22. Schwartz, L. H. et al. Recist 1.1-update and clarification: From the recist committee. European journal of cancer 62, $132-137$ (2016).

23. Kassambara, A., Kosinski, M., Biecek, P. \& Fabian, S. Package 'survminer'. Drawing Survival Curves using 'ggplot2'.(R package version 0.3. 1.) (2017).

24. Peto, R. \& Peto, J. Asymptotically efficient rank invariant test procedures. Journal of the Royal Statistical Society: Series A (General) 135, 185-198 (1972).

25. Zilionis, R. et al. Single-cell transcriptomics of human and mouse lung cancers reveals conserved myeloid populations across individuals and species. Immunity 50, 1317-1334 (2019).

Weinreb, C., Wolock, S. \& Klein, A. M. Spring: a kinetic interface for visualizing high dimensional single-cell expression data. Bioinformatics 34, 1246-1248 (2018).

27. Jerby-Arnon, L. et al. A cancer cell program promotes t cell exclusion and resistance to checkpoint blockade. Cell 175, 984-997 (2018).

28. Maaten, L. v. d. \& Hinton, G. Visualizing data using t-sne. Journal of machine learning research 9, 2579-2605 (2008).

29. Mann, H. B. \& Whitney, D. R. On a test of whether one of two random variables is stochastically larger than the other. The annals of mathematical statistics $50-60$ (1947).

30. Breitling, R., Armengaud, P., Amtmann, A. \& Herzyk, P. Rank products: a simple, yet powerful, new method to detect differentially regulated genes in replicated microarray experiments. FEBS letters 573, 83-92 (2004).

31. Hong, F. \& Breitling, R. A comparison of meta-analysis methods for detecting differentially expressed genes in microarray experiments. Bioinformatics 24, 374-382 (2008). 
bioRxiv preprint doi: https://doi.org/10.1101/2020.02.19.955666; this version posted February 28, 2020. The copyright holder for this preprint (which was not certified by peer review) is the author/funder, who has granted bioRxiv a license to display the preprint in perpetuity. It is made available under aCC-BY-ND 4.0 International license.

\section{Appendix S2: supplementary figures}

(A)

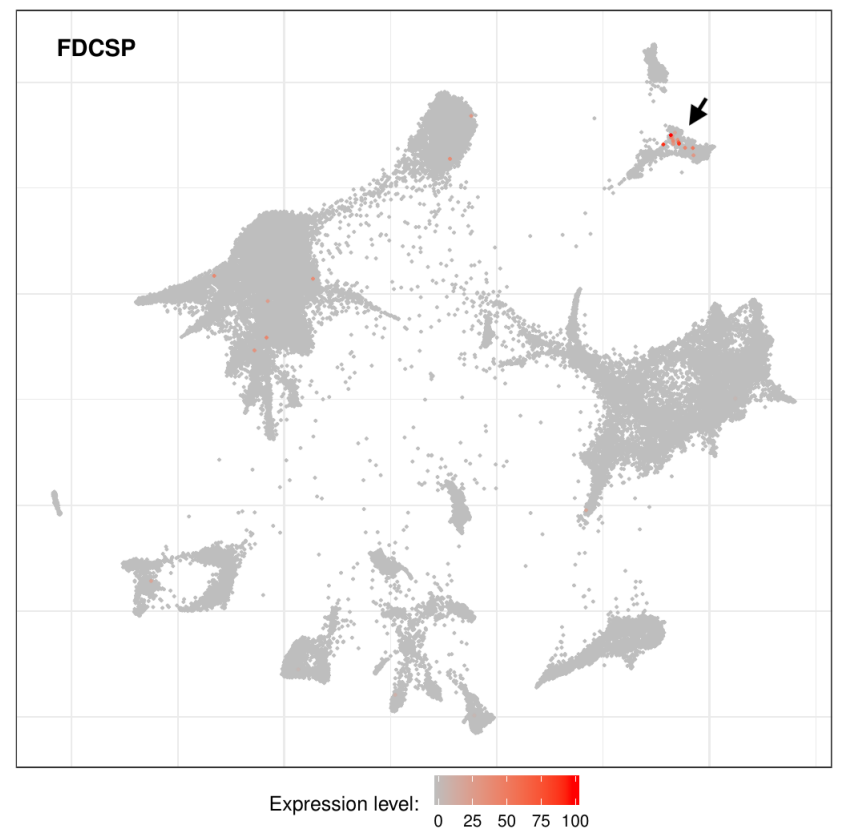

(C)

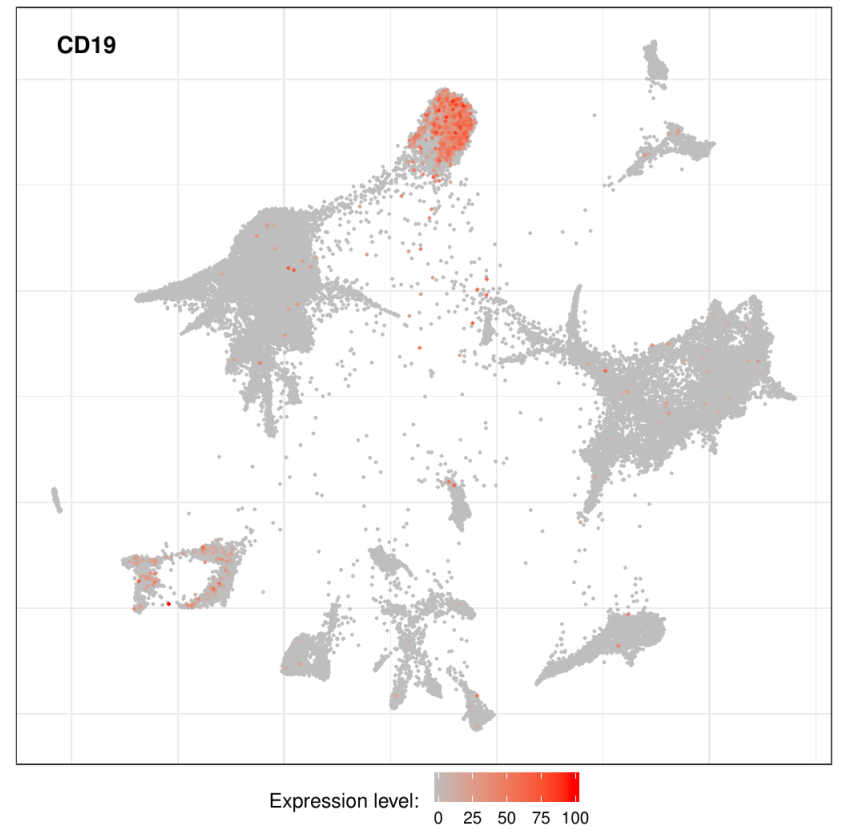

(B)

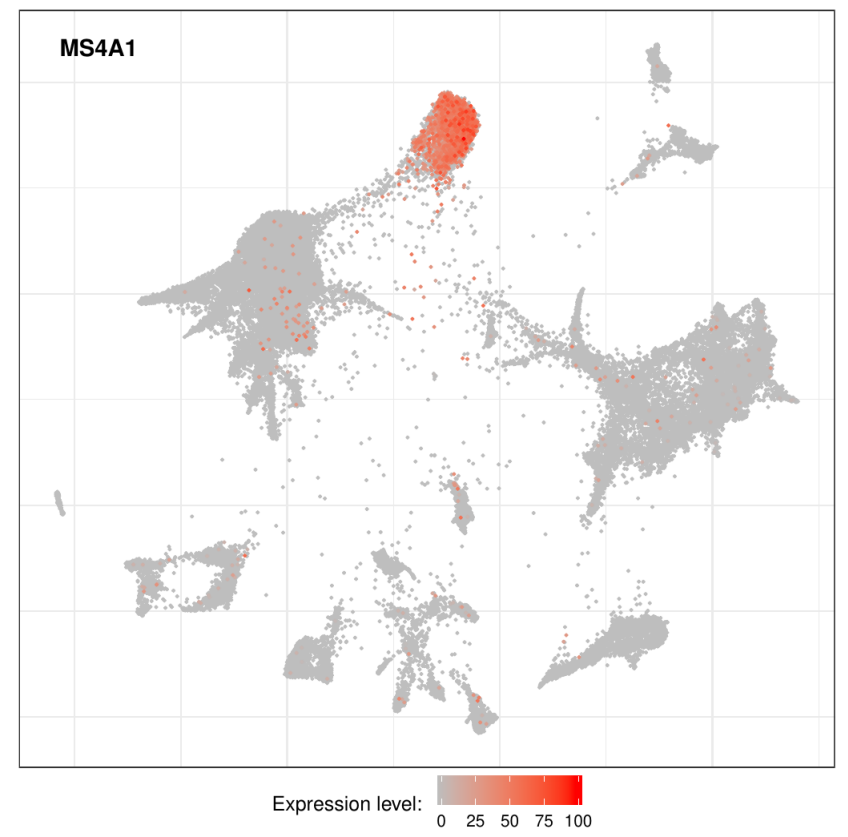

(D)

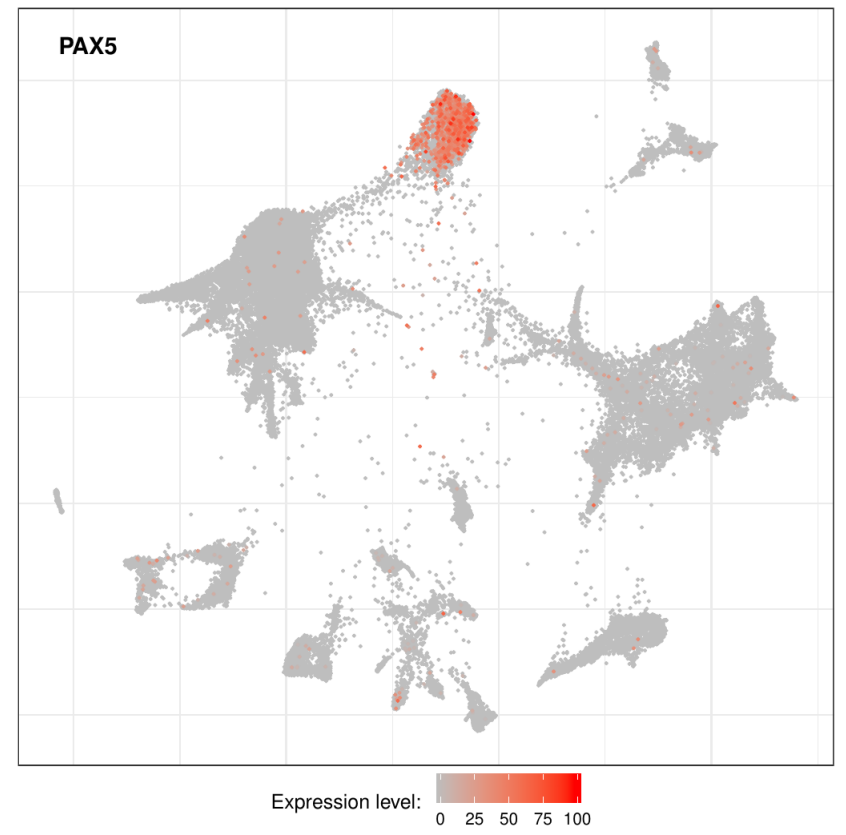

Fig. S1. FDCSP is not expressed in B cells infiltrating lung cancer tumours. Two-dimensional visualizations (SPRING plots) of single-cell RNA sequencing data obtained from lung cancer tumours and published in (25). Each dot represents the transcriptional profile of a single cell. Cells closely associated in each plot are more likely to transcribe similar genes and might thus belong to the same cell type. Expression values and coordinates for each dot were obtained from the original study. The color scale indicates expression level for a particular gene ranging from 0 (minimum expression value observed in the dataset for that gene, usually corresponding to non detectable expression) to 100 (maximum expression value observed in the dataset for that gene). Expression of $F D C S P$ is observed in a group of cells indicated by the black arrow in (A) well distinct from cells expressing prototypical B cell markers (B-D). 
bioRxiv preprint doi: https://doi.org/10.1101/2020.02.19.955666; this version posted February 28, 2020. The copyright holder for this preprint (which was not certified by peer review) is the author/funder, who has granted bioRxiv a license to display the preprint in perpetuity. It is made available under aCC-BY-ND 4.0 International license.

(A)

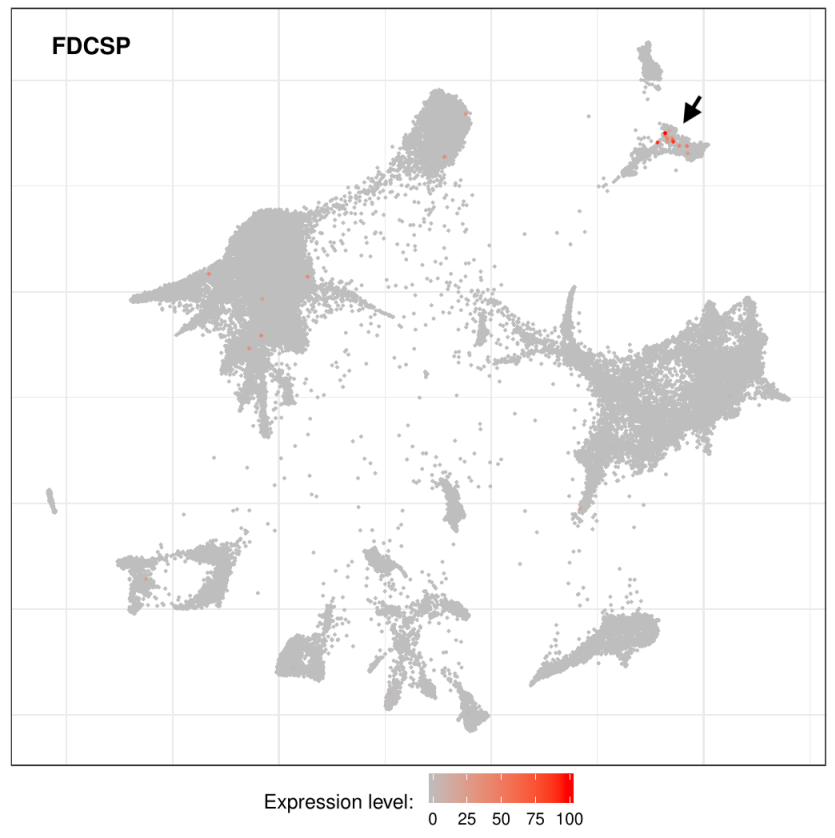

(C)

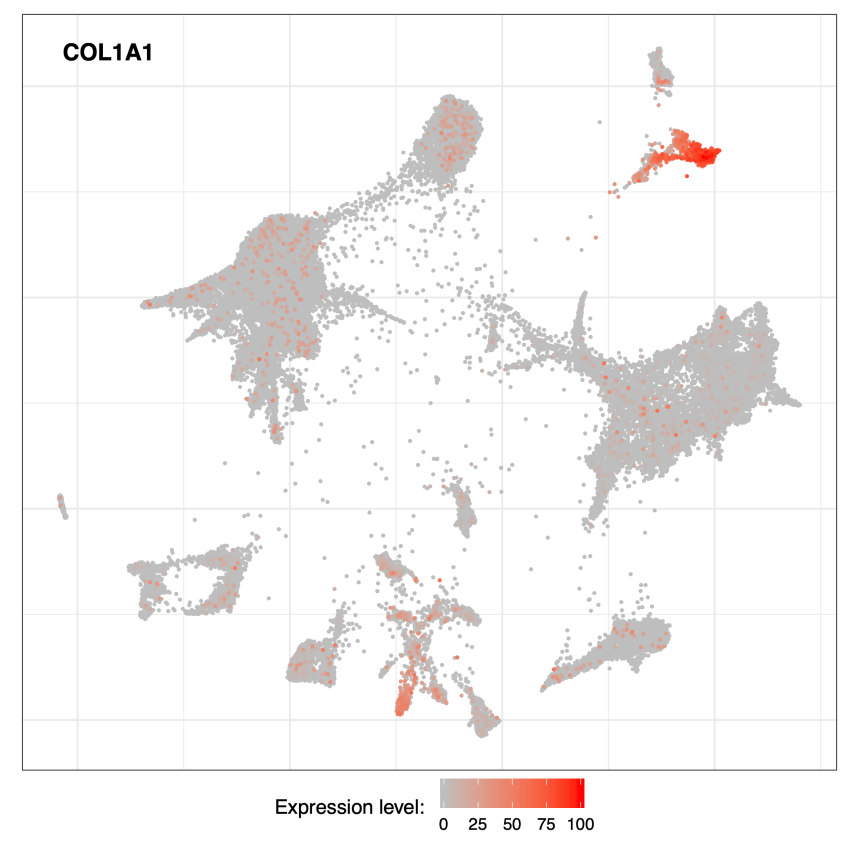

(B)

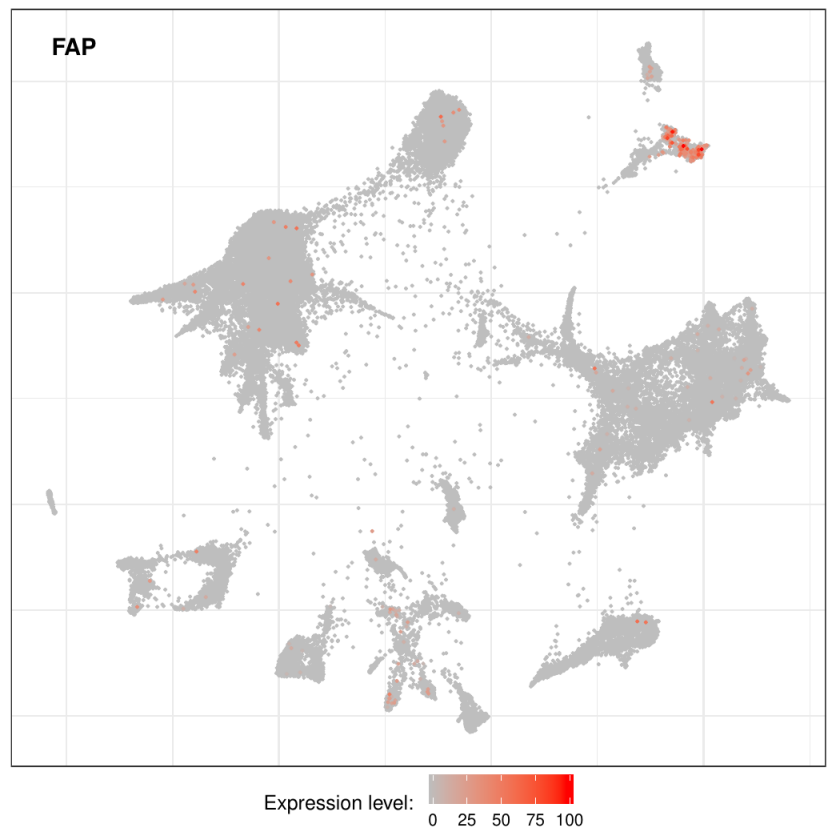

(D)

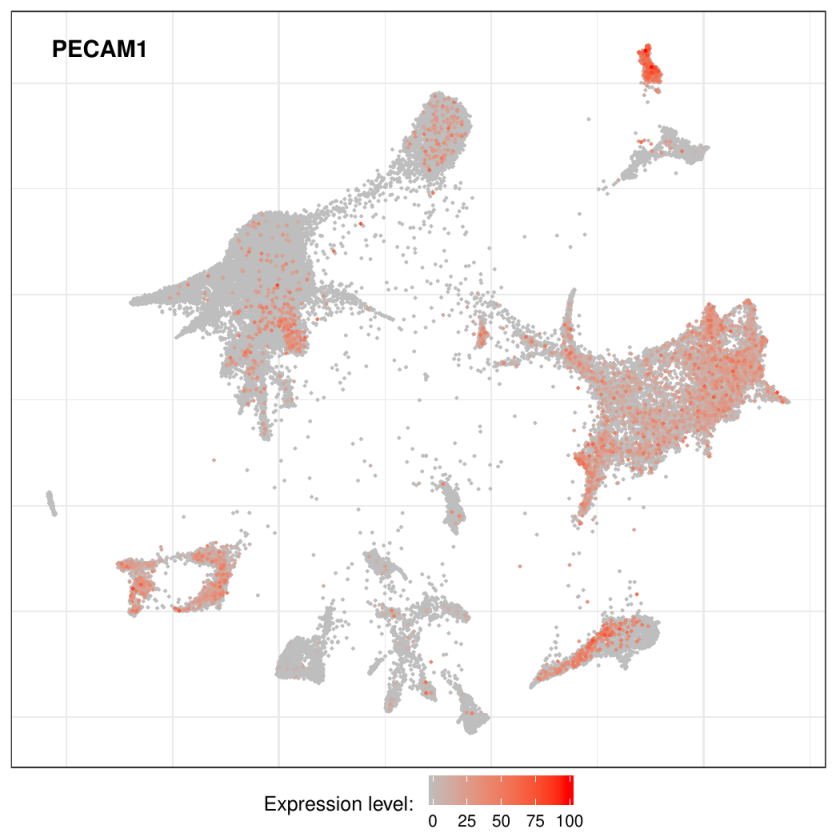

Fig. S2. | FDCSP is expressed in a subset of fibroblasts in lung cancer tumours. Two-dimensional visualizations (SPRING plots) of single-cell RNA sequencing data obtained from lung cancer tumours and published in (25). Each dot represents the transcriptional profile of a single cell. Cells closely associated in each plot are more likely to transcribe similar genes and might thus belong to the same cell type. Expression values and coordinates for each dot were obtained from the original study. The color scale indicates expression level for a particular gene ranging from 0 (minimum expression value observed in the dataset for that gene, usually corresponding to non detectable expression) to 100 (maximum expression value observed in the dataset for that gene). A. Expression of FDCSP. The black arrow indicates a group of transcriptionally related cells containing FDCSP+ cells. B. Expression of FAP. C. Expression of COL1A1. D. Expression of PECAM1/CD31. 
bioRxiv preprint doi: https://doi.org/10.1101/2020.02.19.955666; this version posted February 28, 2020. The copyright holder for this preprint (which was not certified by peer review) is the author/funder, who has granted bioRxiv a license to display the preprint in perpetuity. It is made available under aCC-BY-ND 4.0 International license.

(A)

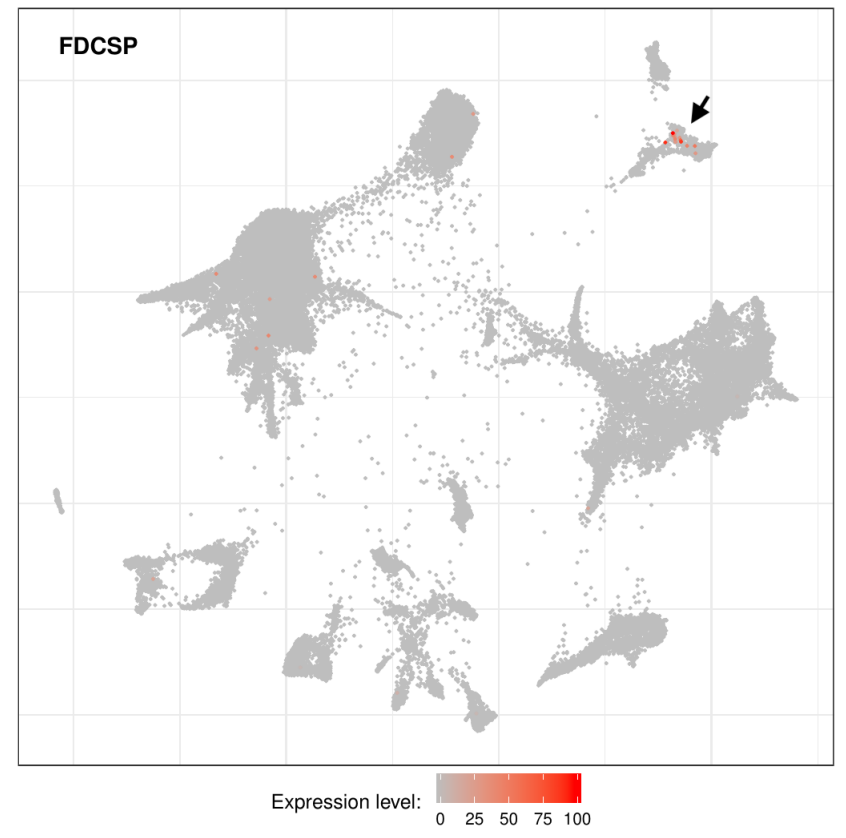

(C)

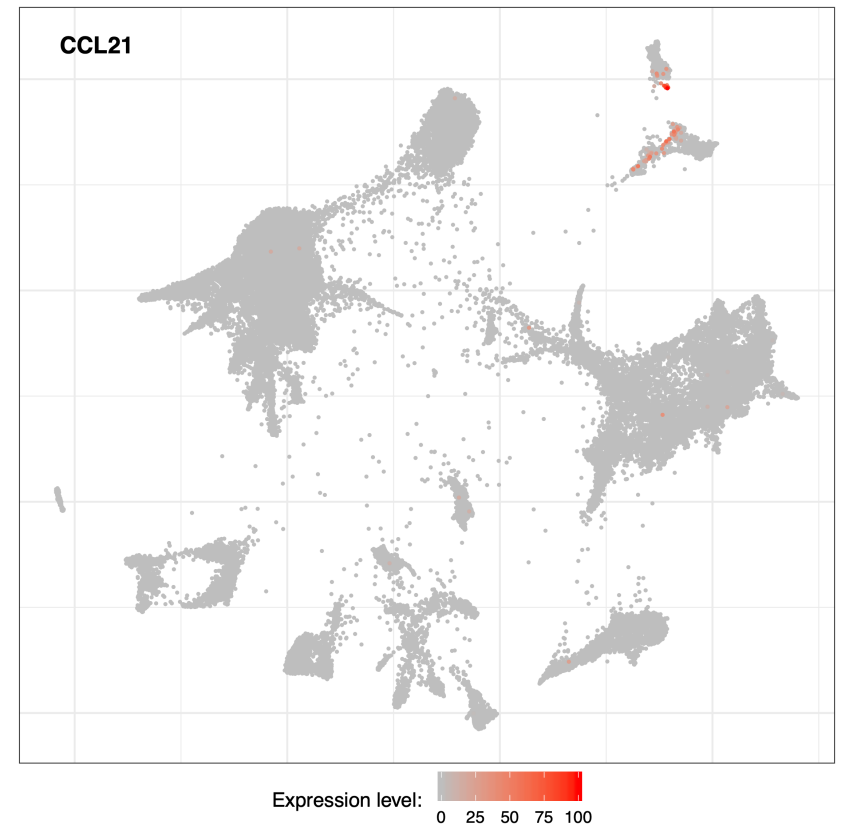

(B)

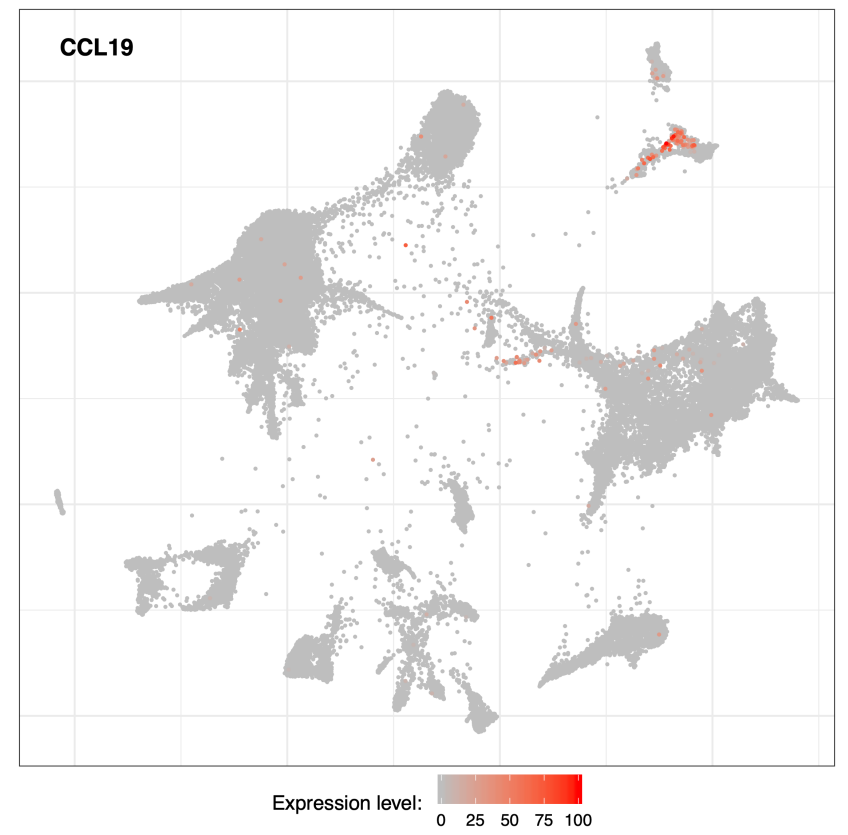

(D)

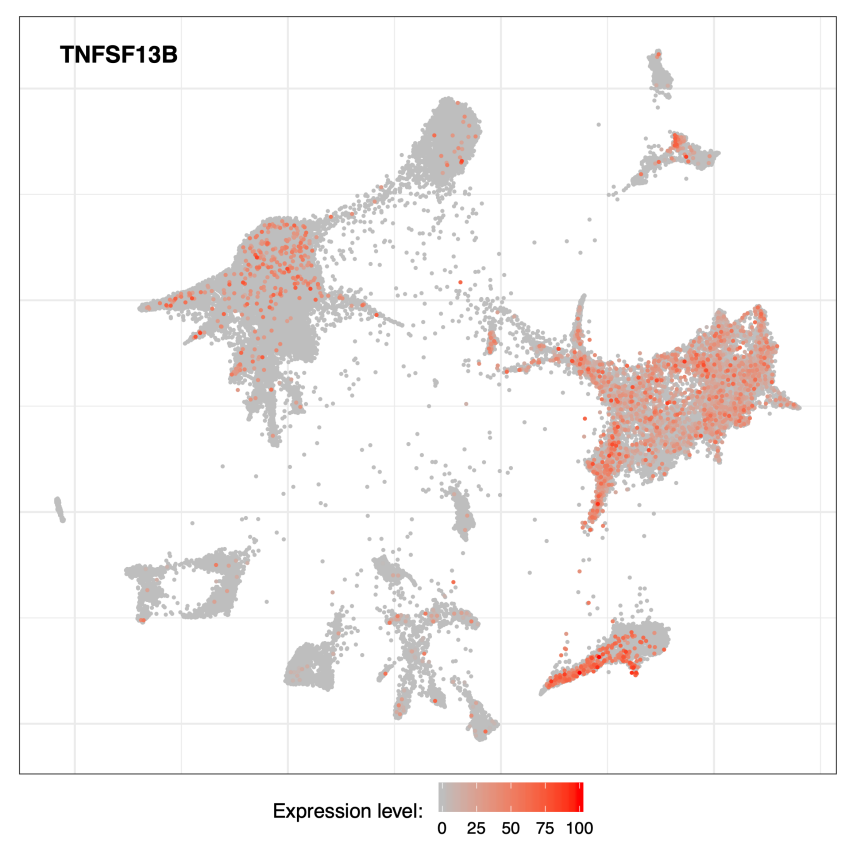

Fig. S3. | FDCSP+ cells express markers of FRCs in lung cancer tumours. Two-dimensional visualizations (SPRING plots) of single-cell RNA sequencing data obtained from lung cancer tumours and published in (25). Each dot represents the transcriptional profile of a single cell. Cells closely associated in each plot are more likely to transcribe similar genes and might thus belong to the same cell type. Expression values and coordinates for each dot were obtained from the original study. The color scale indicates expression level for a particular gene ranging from 0 (minimum expression value observed in the dataset for that gene, usually corresponding to non detectable expression) to 100 (maximum expression value observed in the dataset for that gene). A. Expression of FDCSP. The black arrow indicates a group of transcriptionally related cells containing FDCSP+ cells. B. Expression of CCL19. C. Expression of CCL21. D. Expression of TNFSF13B/BAFF. 
bioRxiv preprint doi: https://doi.org/10.1101/2020.02.19.955666; this version posted February 28, 2020. The copyright holder for this preprint (which was not certified by peer review) is the author/funder, who has granted bioRxiv a license to display the preprint in perpetuity. It is made available under aCC-BY-ND 4.0 International license.

(A)

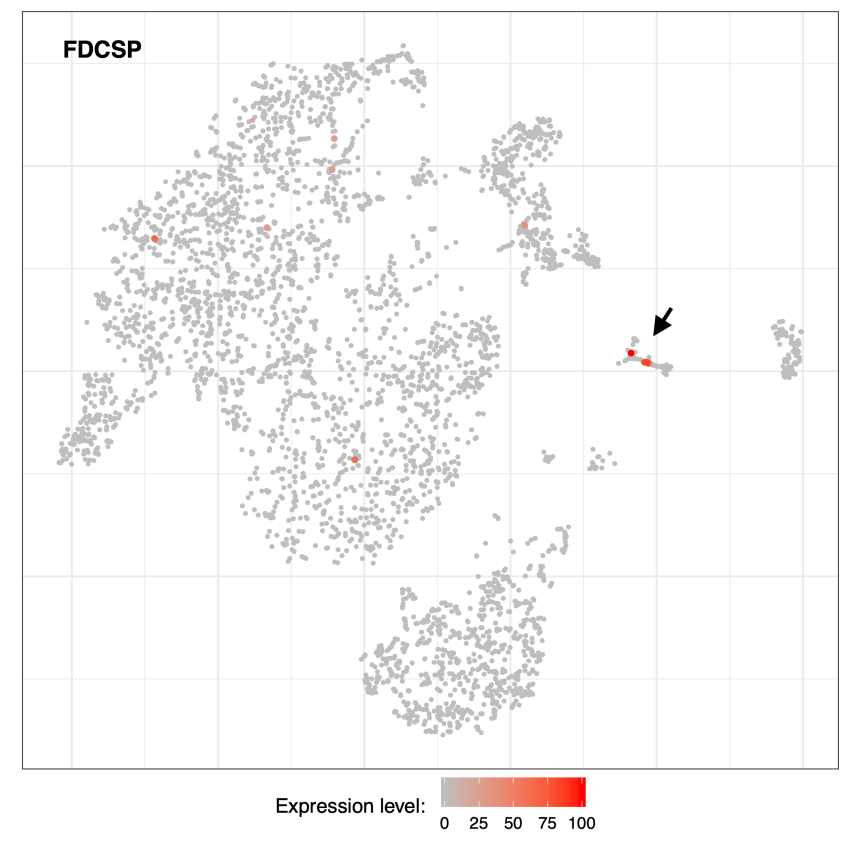

(C)

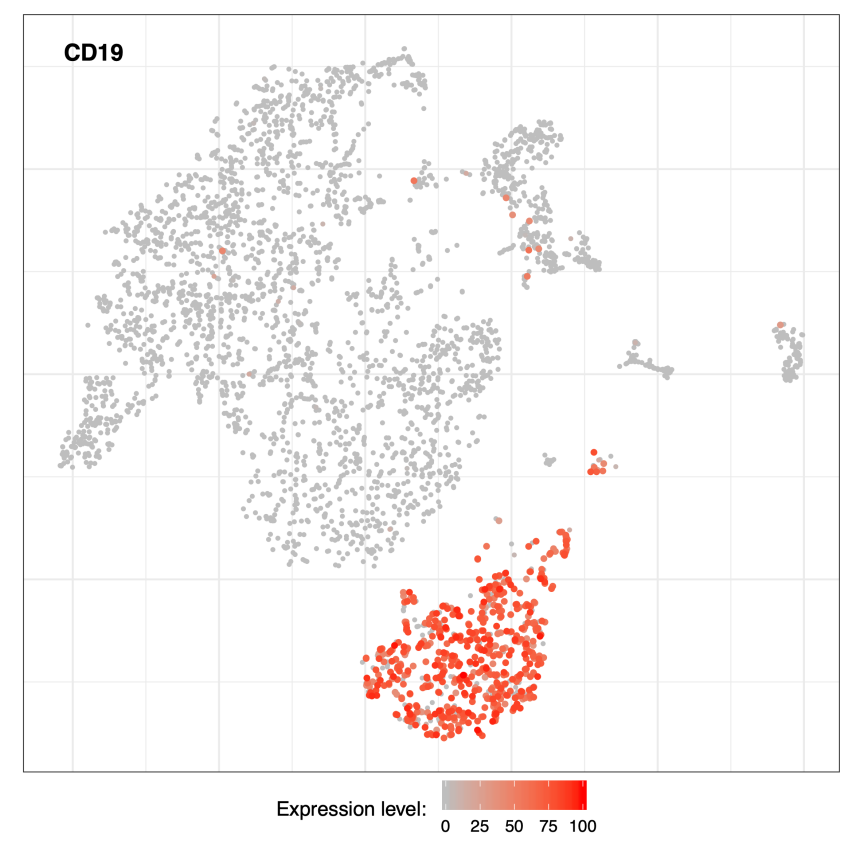

(B)

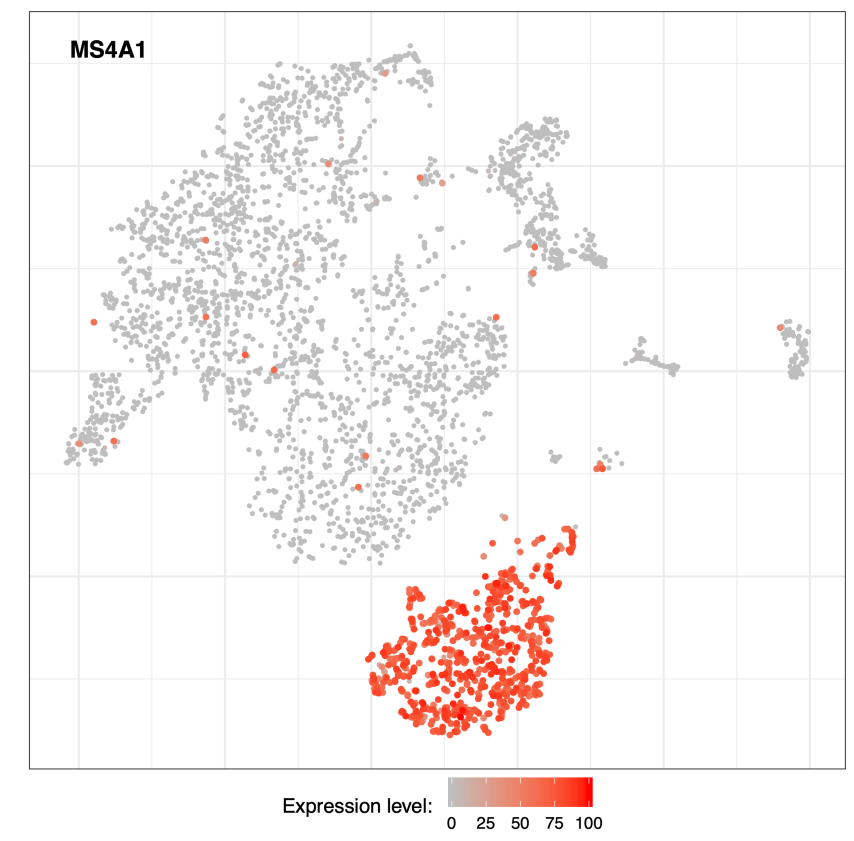

(D)

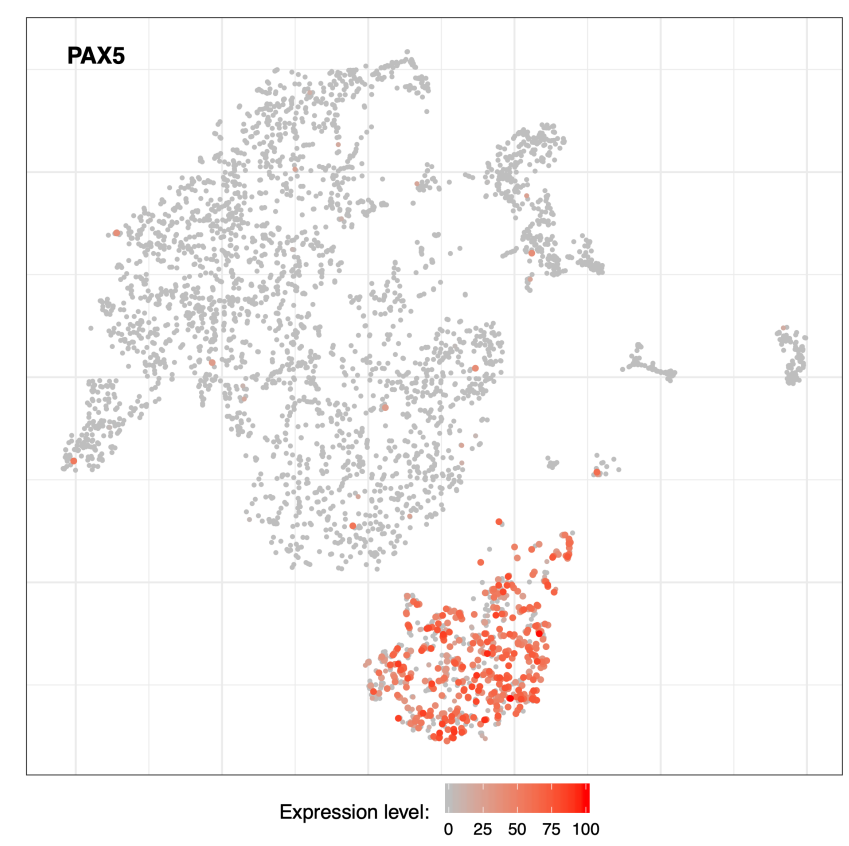

Fig. S4. FDCSP is not expressed in B cells infiltrating melanoma. Two-dimensional visualizations (tSNE plots) of single-cell RNA sequencing data obtained from melanoma tumours and published in (27). Each dot represents the transcriptional profile of a single cell. Cells closely associated in each plot are more likely to transcribe similar genes and might thus belong to the same cell type. Expression values and coordinates for each dot were obtained from the original study. The color scale indicates expression level for a particular gene ranging from 0 (minimum expression value observed in the dataset for that gene, usually corresponding to non detectable expression) to 100 (maximum expression value observed in the dataset for that gene). Expression of FDCSP is observed in a group of cells indicated by a black arrow in (A) well distinct from cells expressing prototypical B cell markers (B-D). 
bioRxiv preprint doi: https://doi.org/10.1101/2020.02.19.955666; this version posted February 28, 2020. The copyright holder for this preprint (which was not certified by peer review) is the author/funder, who has granted bioRxiv a license to display the preprint in perpetuity. It is made available under aCC-BY-ND 4.0 International license.

(A)

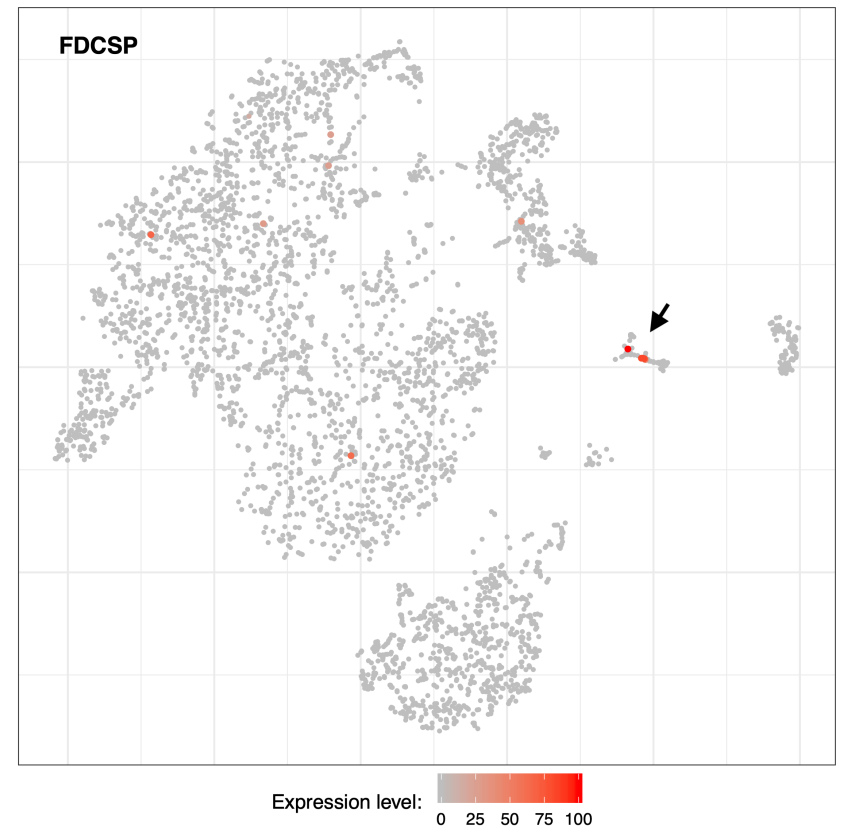

(C)

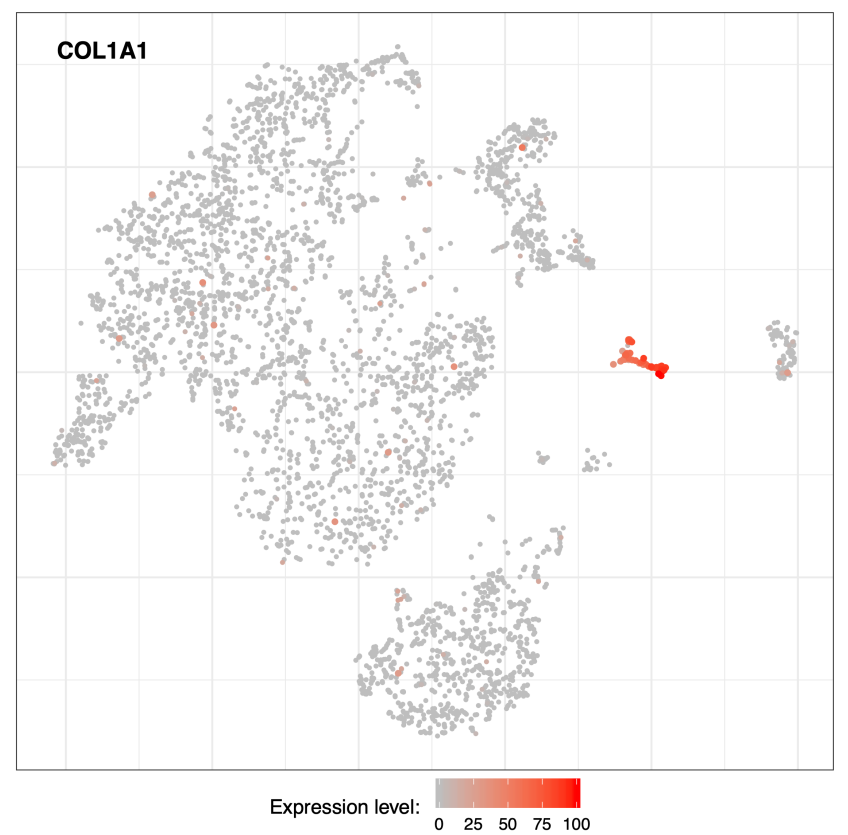

(B)

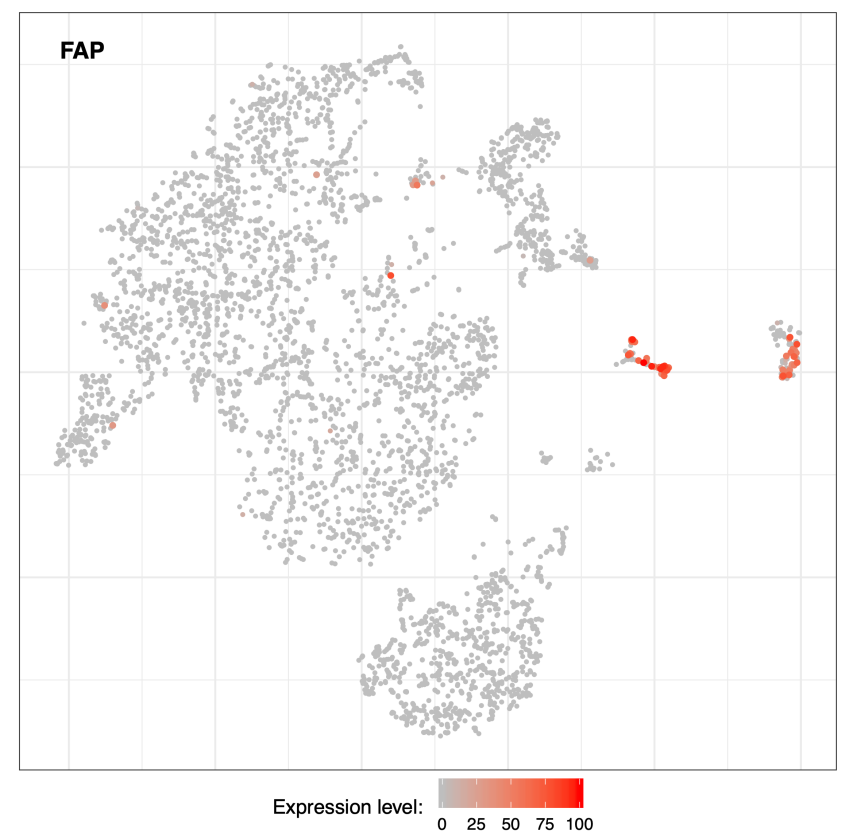

(D)

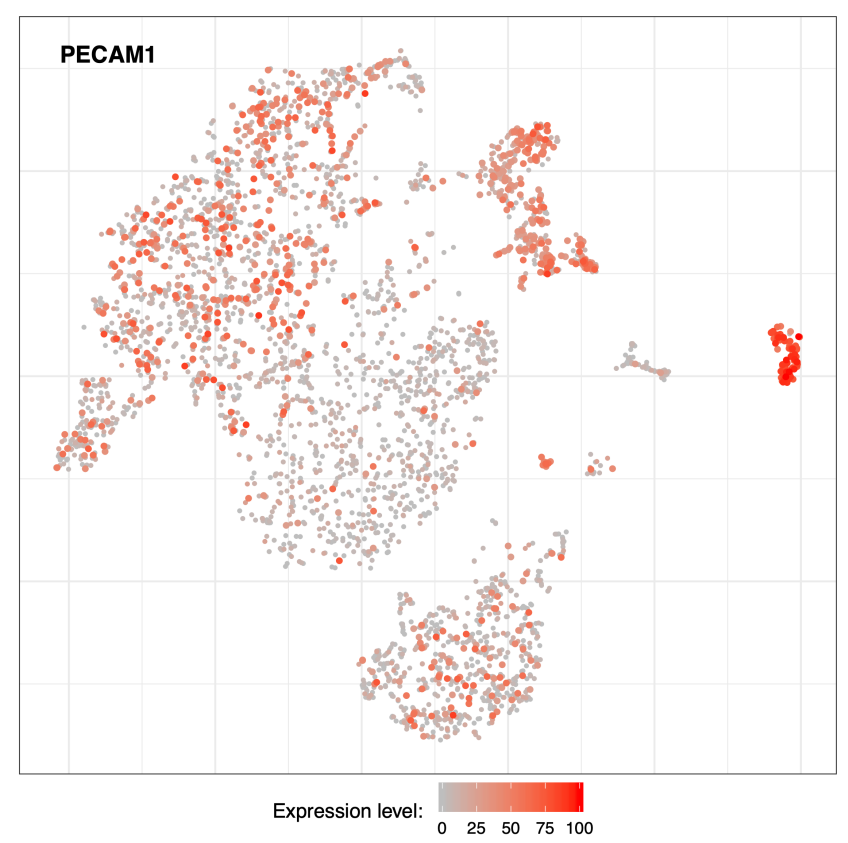

Fig. S5. | FDCSP is expressed in a subset of fibroblasts in melanoma. Two-dimensional visualizations (tSNE plots) of single-cell RNA sequencing data obtained from melanoma tumours and published in (27). Each dot represents the transcriptional profile of a single cell. Cells closely associated in each plot are more likely to transcribe similar genes and might thus belong to the same cell type. Expression values and coordinates for each dot were obtained from the original study. The color scale indicates expression level for a particular gene ranging from 0 (minimum expression value observed in the dataset for that gene, usually corresponding to non detectable expression) to 100 (maximum expression value observed in the dataset for that gene). A. Expression of FDCSP. The black arrow indicates a group of transcriptionally related cells containing FDCSP+ cells. B. Expression of FAP. C. Expression of COL1A1. D. Expression of PECAM1/CD31. 
bioRxiv preprint doi: https://doi.org/10.1101/2020.02.19.955666; this version posted February 28, 2020. The copyright holder for this preprint (which was not certified by peer review) is the author/funder, who has granted bioRxiv a license to display the preprint in perpetuity. It is made available under aCC-BY-ND 4.0 International license.

(A)

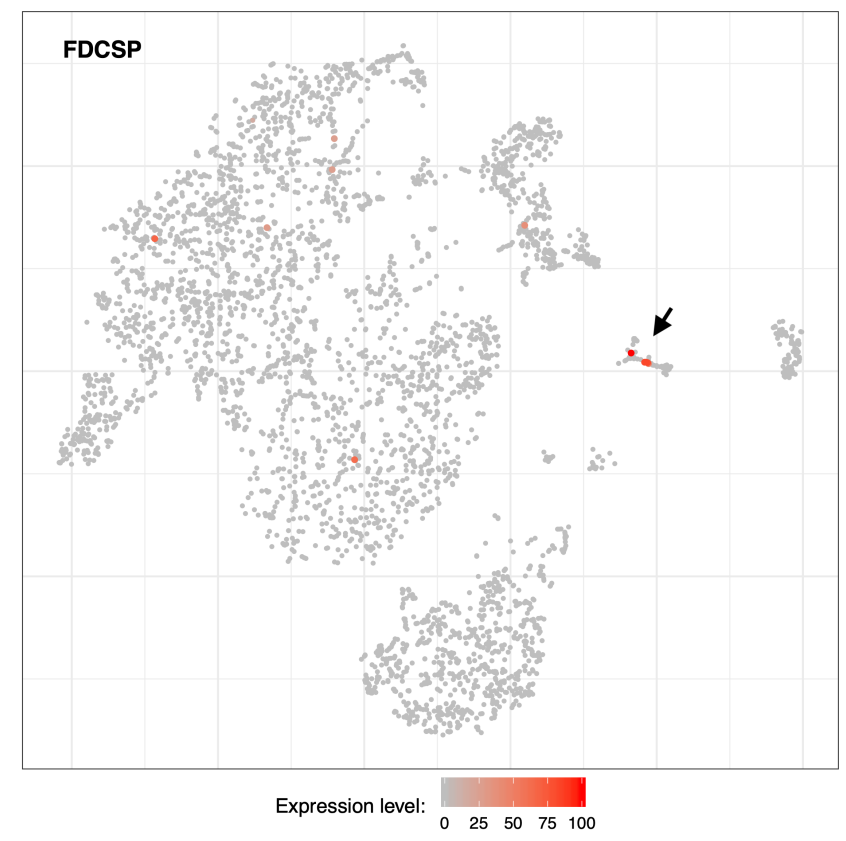

(C)

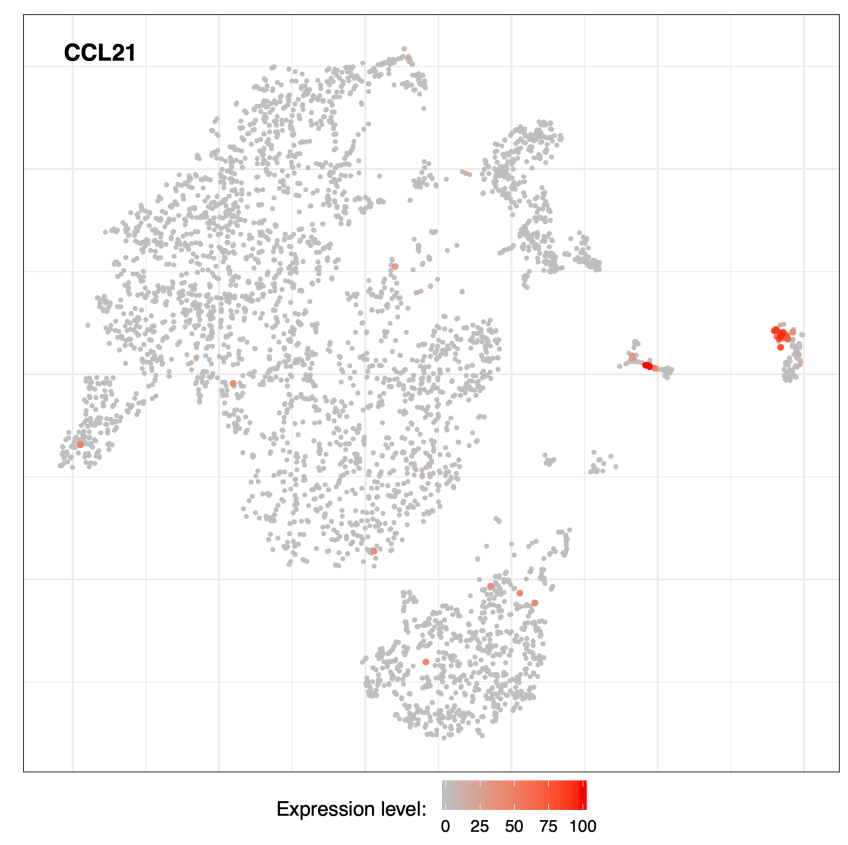

(B)

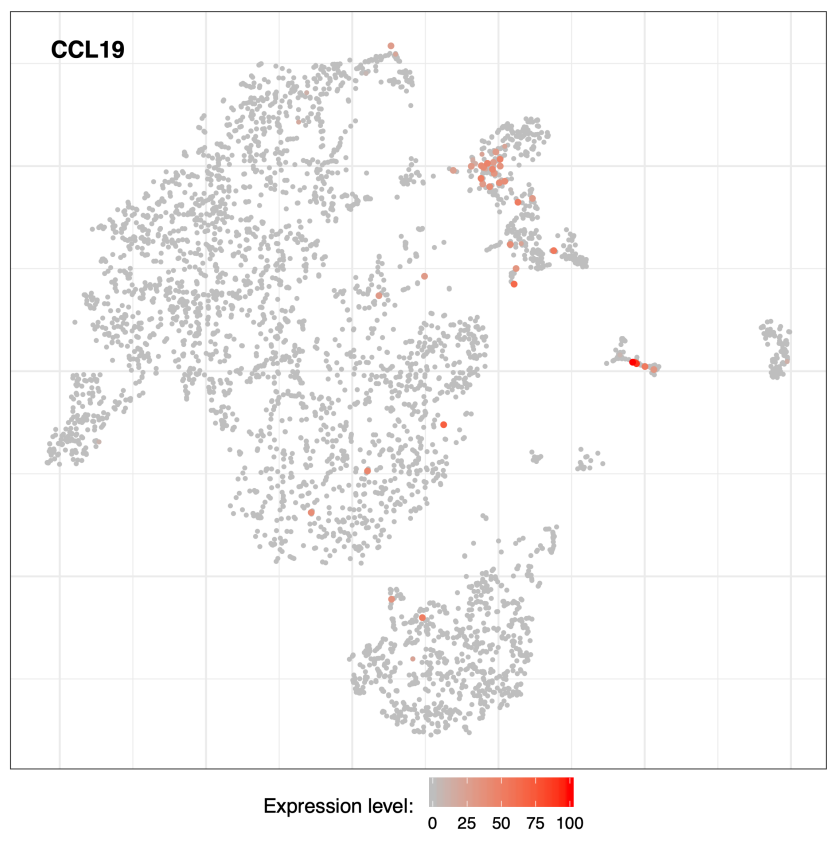

(D)

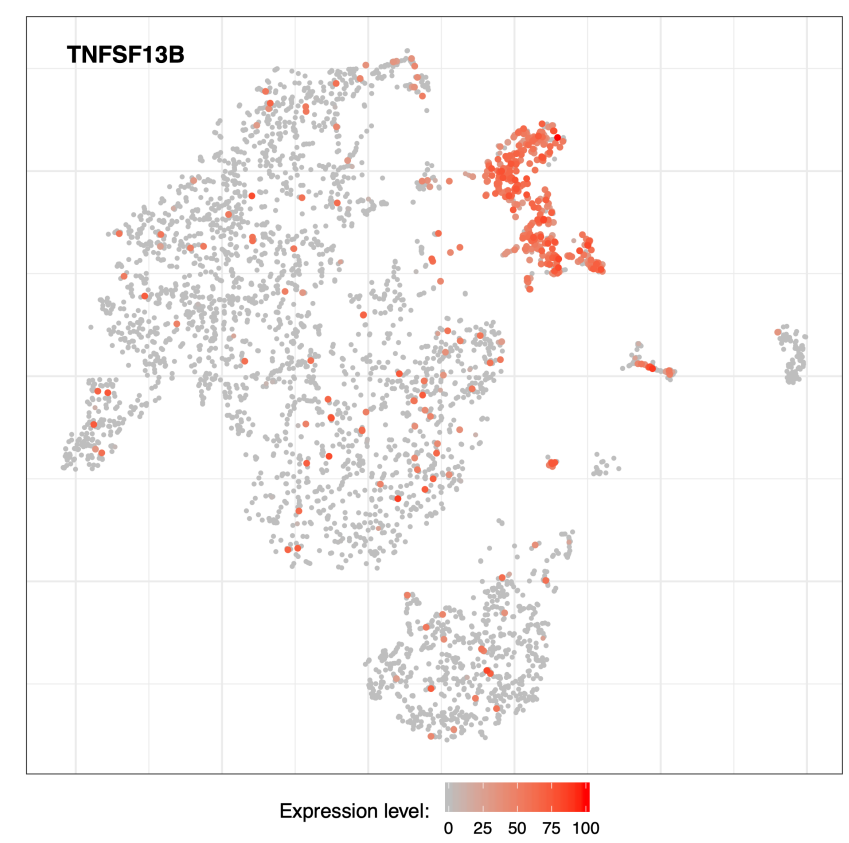

Fig. S6. | FDCSP+ cells express markers of FRCs in melanoma. Two-dimensional visualizations (tSNE plots) of single-cell RNA sequencing data obtained from melanoma tumours and published in (27). Each dot represents the transcriptional profile of a single cell. Cells closely associated in each plot are more likely to transcribe similar genes and might thus belong to the same cell type. Expression values and coordinates for each dot were obtained from the original study. The color scale indicates expression level for a particular gene ranging from 0 (minimum expression value observed in the dataset for that gene, usually corresponding to non detectable expression) to 100 (maximum expression value observed in the dataset for that gene). A. Expression of FDCSP. The black arrow indicates a group of transcriptionally related cells containing FDCSP+ cells. B. Expression of CCL19. C. Expression of CCL21. D. Expression of TNFSF13B/BAFF. 
bioRxiv preprint doi: https://doi.org/10.1101/2020.02.19.955666; this version posted February 28, 2020. The copyright holder for this preprint (which was not certified by peer review) is the author/funder, who has granted bioRxiv a license to display the preprint in perpetuity. It is made available under aCC-BY-ND 4.0 International license.

(A)

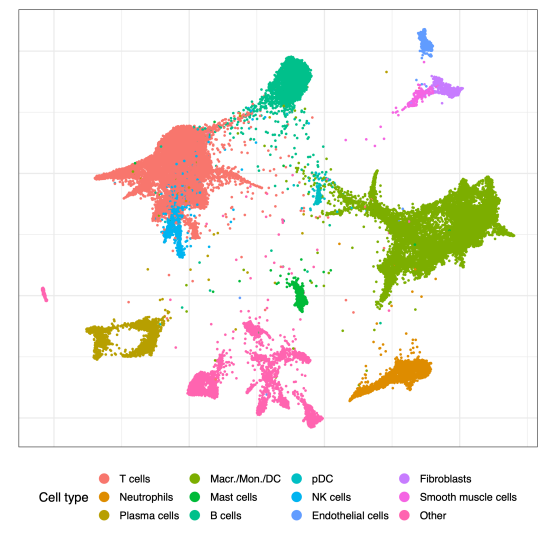

(D)

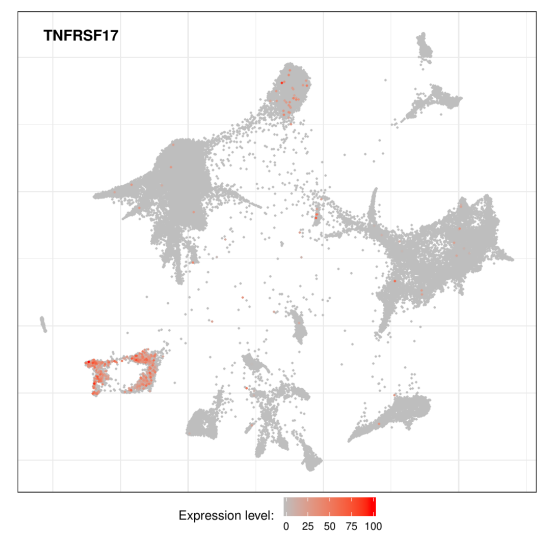

(G)

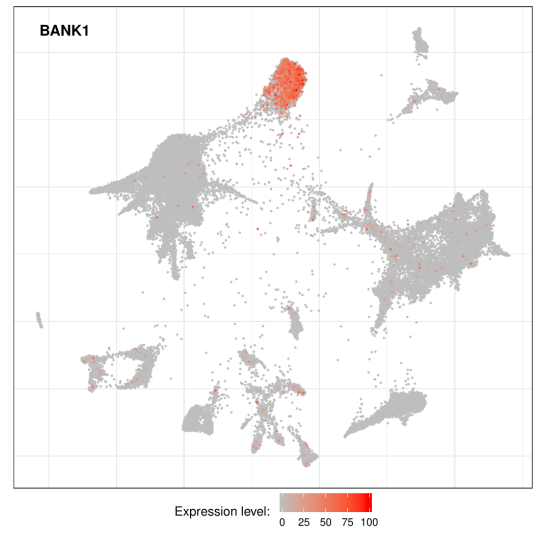

(J)

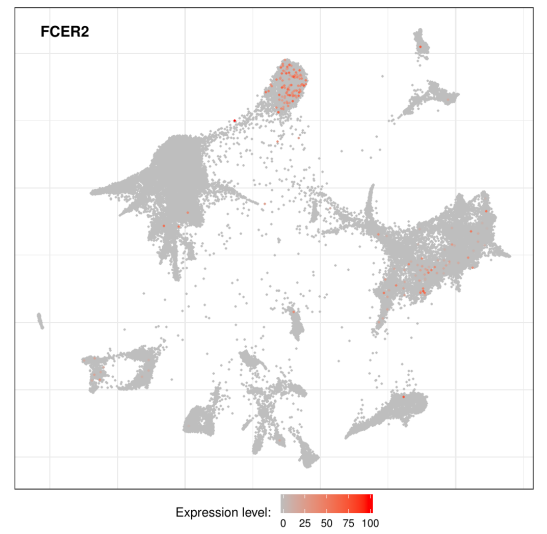

(B)

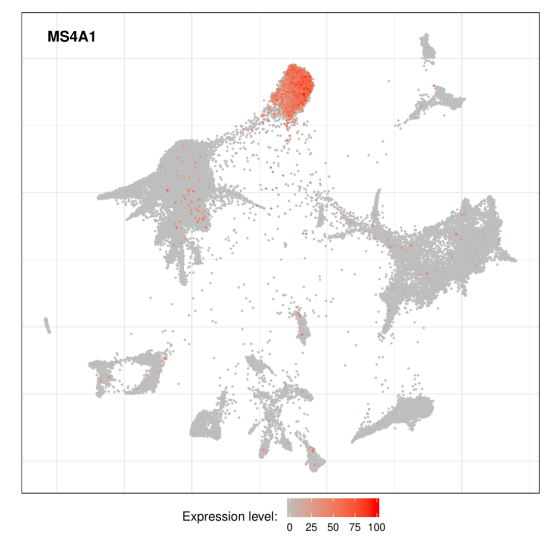

(E)

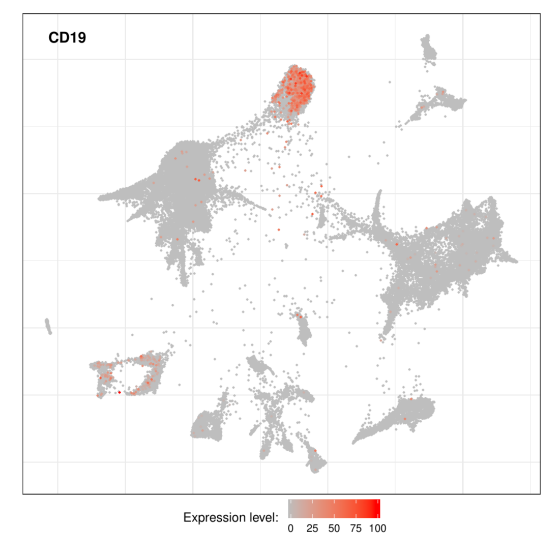

(H)

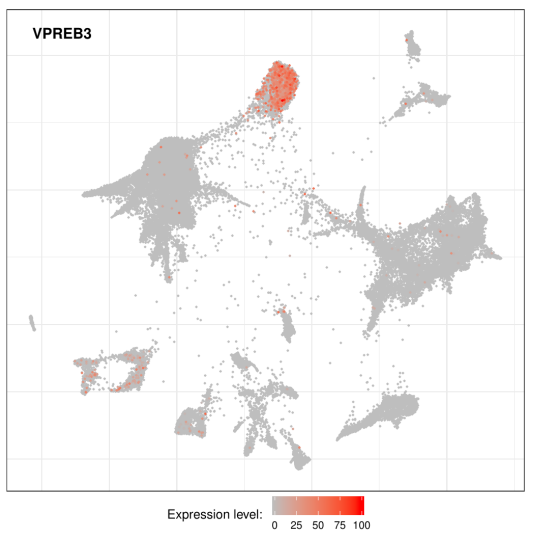

(K)

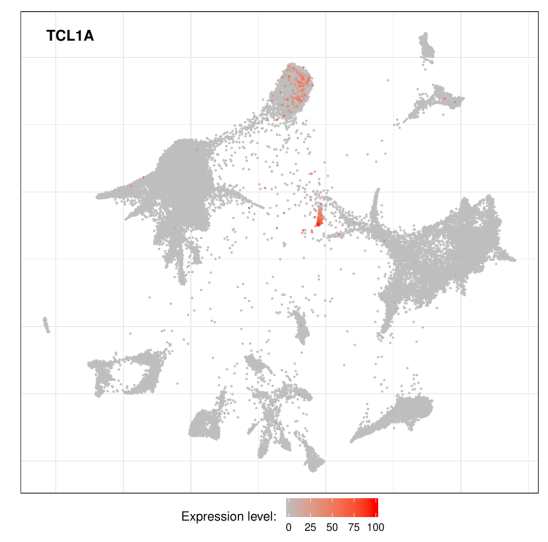

(C)

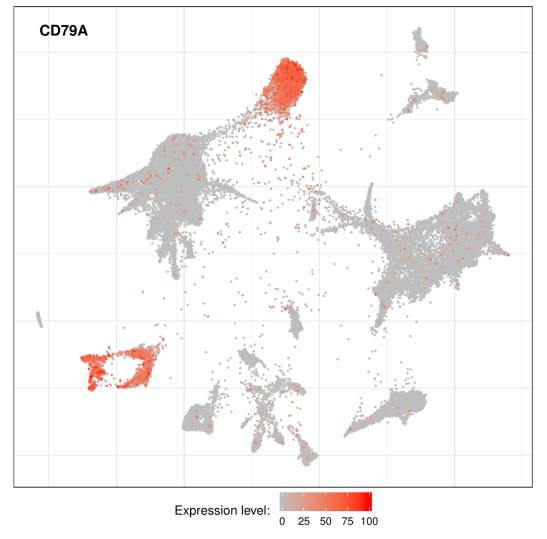

(F)

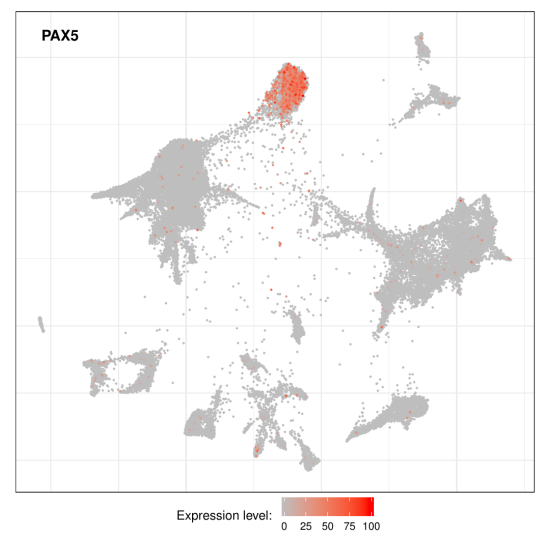

(l)

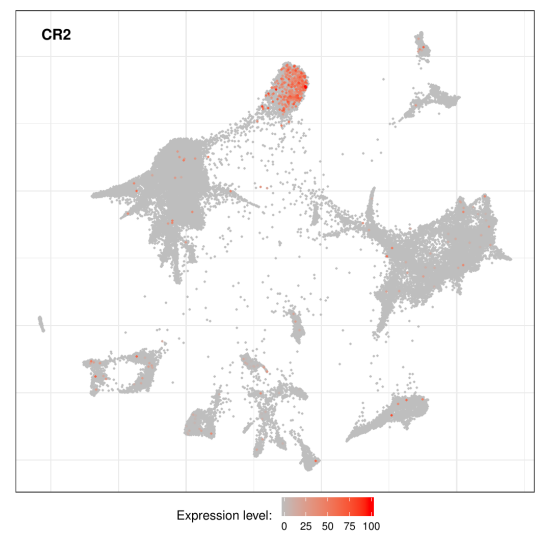

(L)

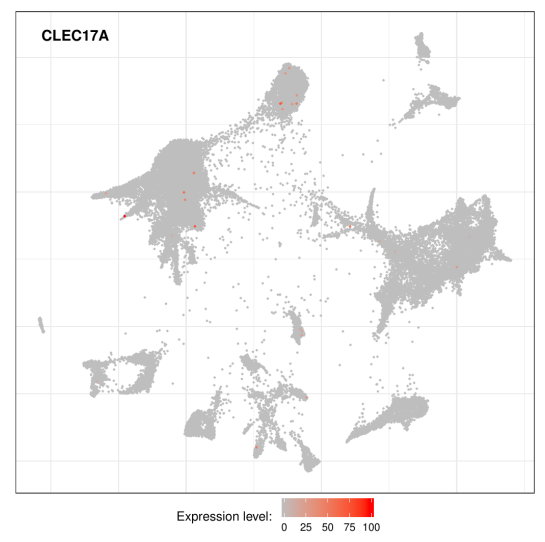


bioRxiv preprint doi: https://doi.org/10.1101/2020.02.19.955666; this version posted February 28, 2020. The copyright holder for this preprint (which was not certified by peer review) is the author/funder, who has granted bioRxiv a license to display the preprint in perpetuity. It is made available under aCC-BY-ND 4.0 International license.

Fig. S7. | Expression of ICI response associated genes in single cells obtained from lung cancer tumours. Two-dimensional visualizations (SPRING plots) of singlecell RNA sequencing data obtained from lung cancer tumours and published in (25). Each dot represents the transcriptional profile of a single cell. Cells closely associated in each plot are more likely to transcribe similar genes and might thus belong to the same cell type. Expression values and coordinates for each dot were obtained from the original study. The expression level color scale indicates expression level for a particular gene ranging from 0 (minimum expression value observed in the dataset for that gene, usually corresponding to non detectable expression) to 100 (maximum expression value observed in the dataset for that gene). Panels $B$ and $C$ are included in the figure in order to further confirm the identity of cells annotated as "B cells" and "Plasma cells" in panel A. A. Cell types annotation as reported in the original study (25). B. Expression of MS4A1/CD20. D. Expression of $C D 79 A$ is detectable in B cells and Plasma cells as expected. D. Expression of TNFRSF17/BCMA is detectable in Plasma cells but not in B cells as expected. E. Expression of CD19. F. Expression of PAX5. G. Expression of BANK1. H. Expression of VPREB3. I. Expression of CR2. J. Expression of FCER2. K. Expression of TCL1A, also detectable in Plasmacytoid dendritic cells (pDC, see panel A). L. Expression of CLEC17A. 
bioRxiv preprint dol: https://doi.org/10.1101/2020.02.19.955666; this version posted February 28, 2020. The copyright holder for this preprint (which was not certified by peer review) is the author/funder, who has granted bioRxiv a license to display the preprint in perpetuity. It is made available under aCC-BY-ND 4.0 International license.

(A)

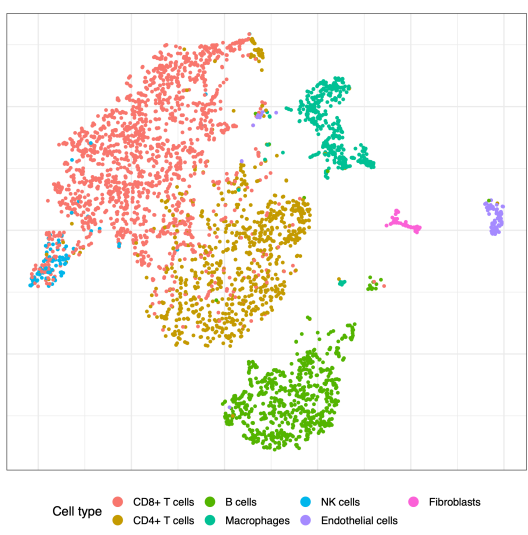

(D)

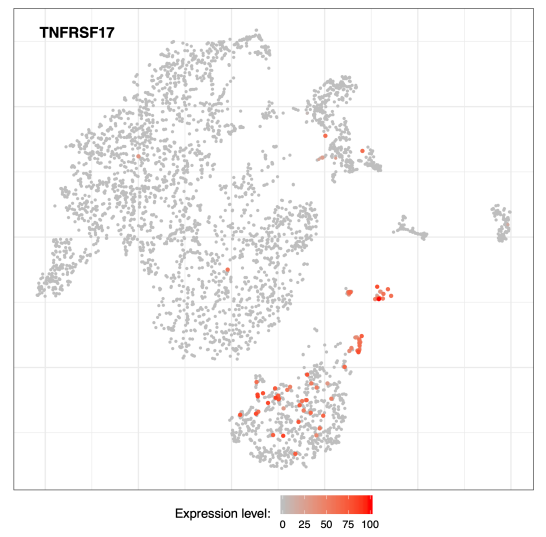

(G)

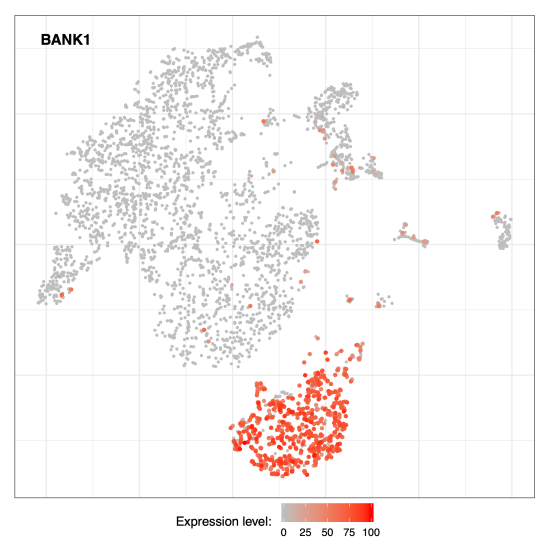

(J)

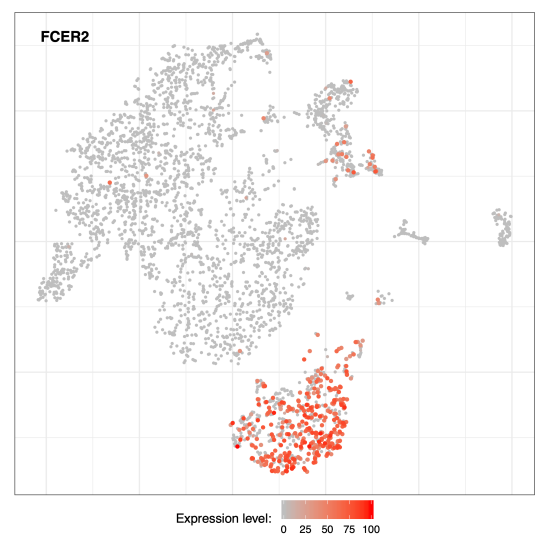

(B)

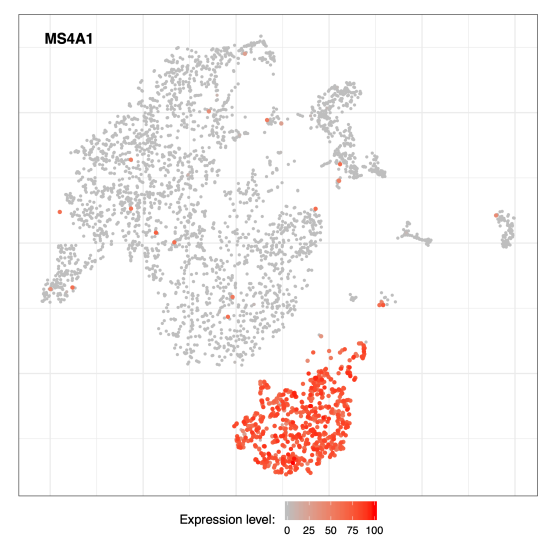

(E)

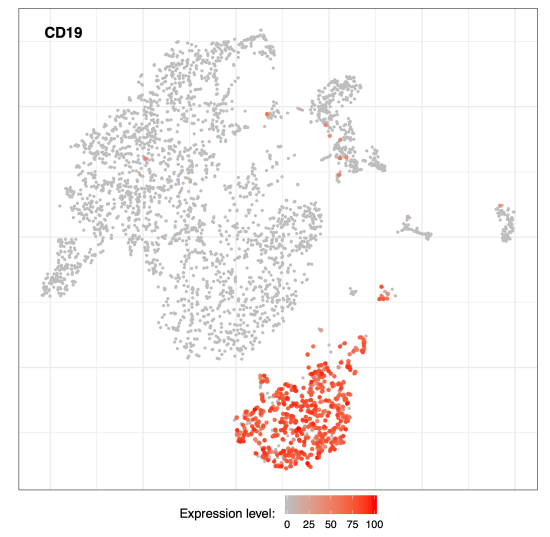

(H)

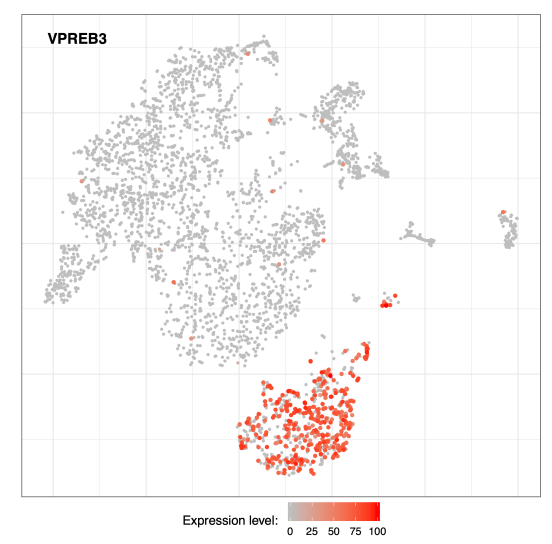

(K)

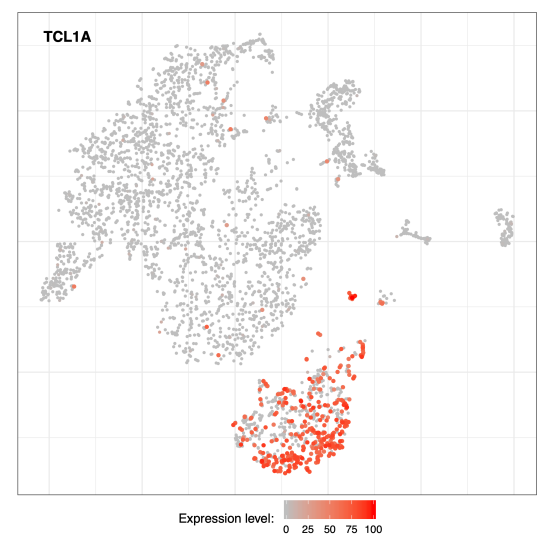

(C)

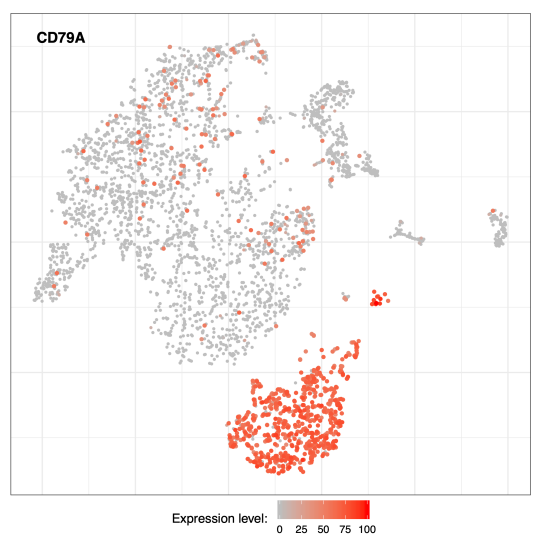

(F)

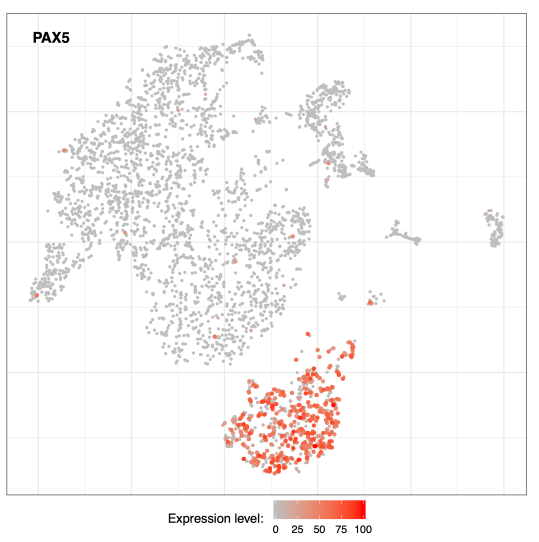

(I)

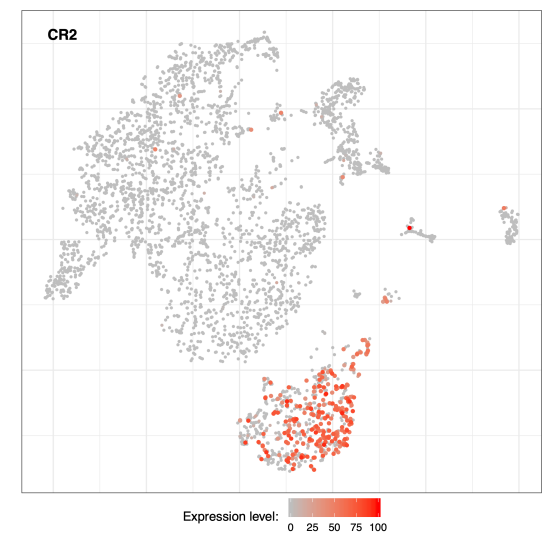

(L)

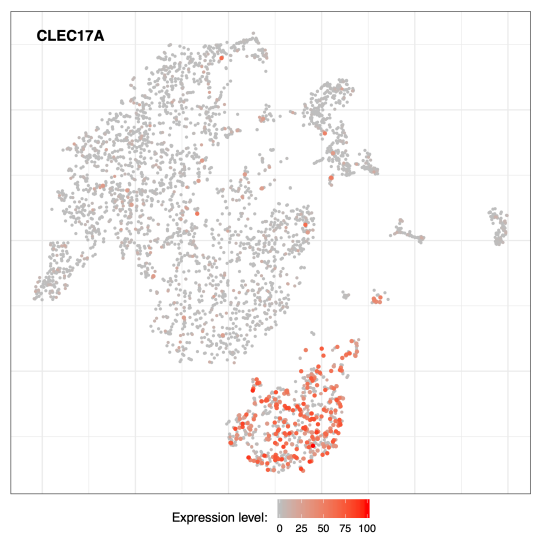

S16 |

Biasci et al. | Fibroblastic reticular cells predict response to immune checkpoint inhibitors 
bioRxiv preprint doi: https://doi.org/10.1101/2020.02.19.955666; this version posted February 28, 2020. The copyright holder for this preprint (which was not certified by peer review) is the author/funder, who has granted bioRxiv a license to display the preprint in perpetuity. It is made available under aCC-BY-ND 4.0 International license.

Fig. S8. | Expression of ICI response associated genes in single cells obtained from melanoma tumours. Two-dimensional visualizations (tSNE plots) of single-cell RNA sequencing data obtained from melanoma tumours and published in (27). Each dot represents the transcriptional profile of a single cell. Cells closely associated in each plot are more likely to transcribe similar genes and might thus belong to the same cell type. Expression values and coordinates for each dot were obtained from the original study. The expression level color scale indicates expression level for a particular gene ranging from 0 (minimum expression value observed in the dataset for that gene, usually corresponding to non detectable expression) to 100 (maximum expression value observed in the dataset for that gene). Panels $B$ and $C$ are included in the figure in order to further confirm the identity of cells annotated as "B cells" and "Plasma cells" in panel A. A. Cell types annotation as reported in the original study (27). B. Expression of $M S 4 A 1 / C D 20$. D. Expression of CD79A D. Expression of TNFRSF17/BCMA. A small cluster of Plasma cells might be visible but was not clearly annotated in this dataset (see panel A). E. Expression of CD19. F. Expression of PAX5. G. Expression of BANK1. H. Expression of VPREB3. I. Expression of CR2. J. Expression of FCER2. K. Expression of TCL1A. A small cluster of pDC might be visible but was not clearly annotated in this dataset (see panel A). L. Expression of CLEC17A. 
bioRxiv preprint doi: https://doi.org/10.1101/2020.02.19.955666; this version posted February 28, 2020. The copyright holder for this preprint (which was not certified by peer review) is the author/funder, who has granted bioRxiv a license to display the preprint in perpetuity. It is made available under aCC-BY-ND 4.0 International license.

(A)

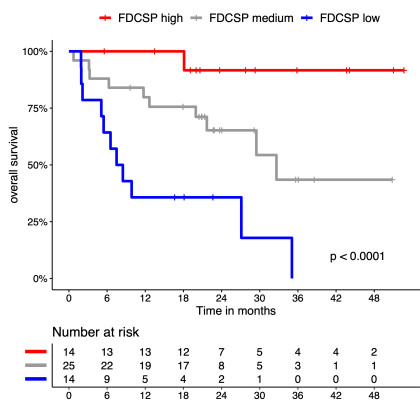

(E)

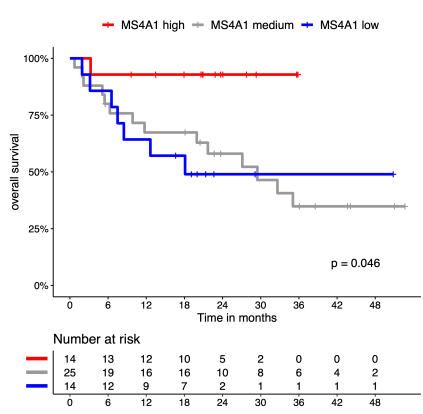

(l)

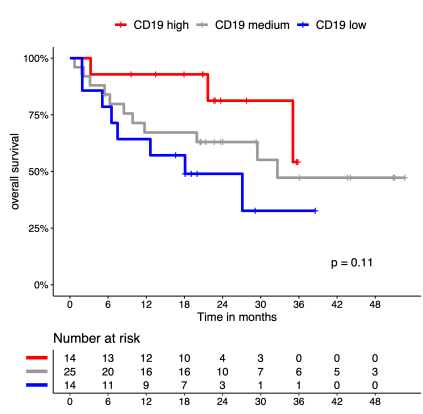

(M)

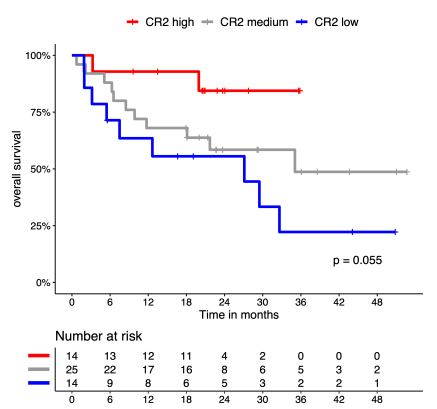

(B)

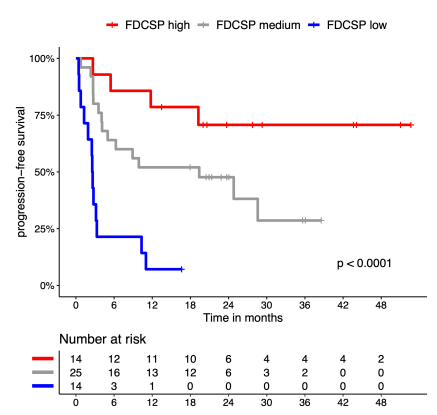

(F)

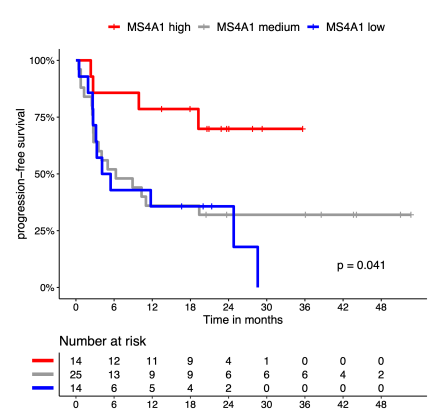

(J)

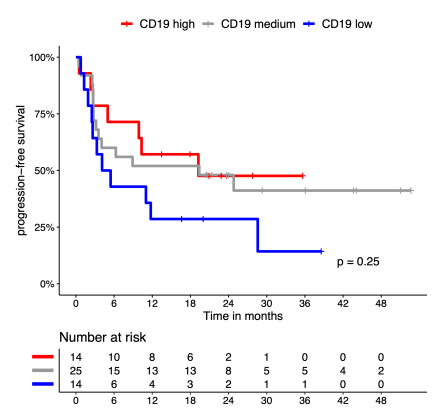

(N)

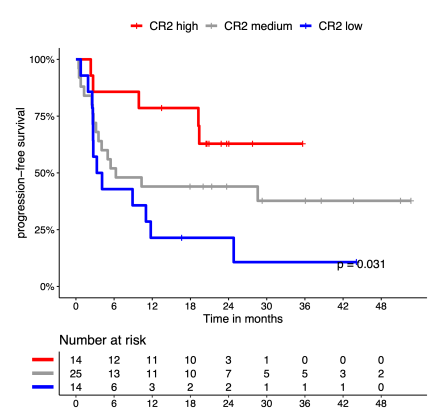

(C)

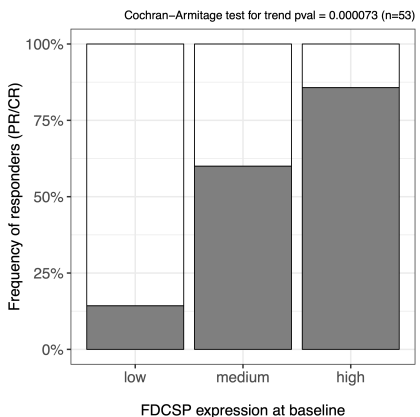

(G)

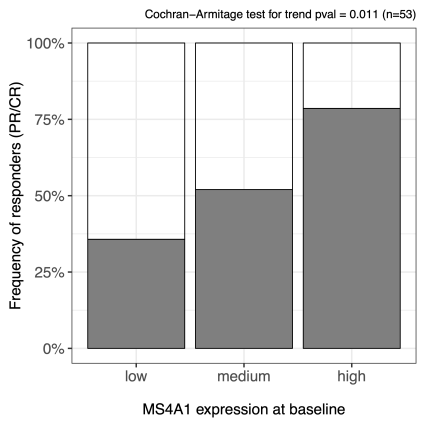

(K)

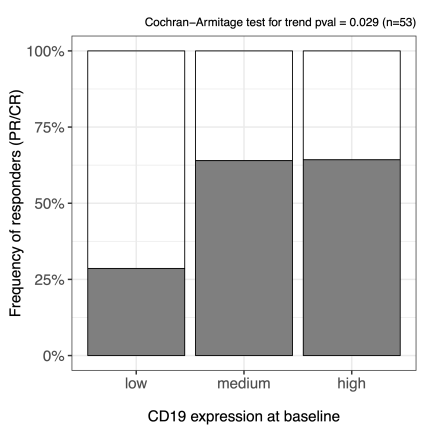

(0)

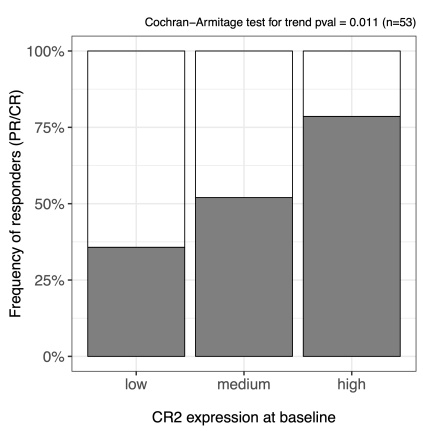

(D)

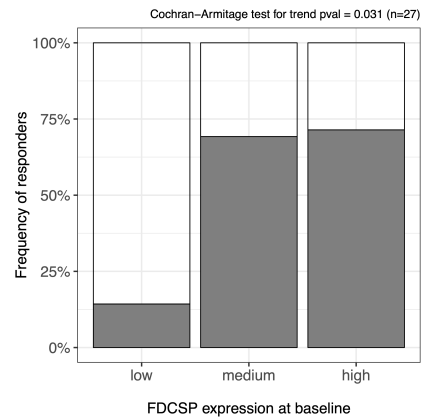

(H)

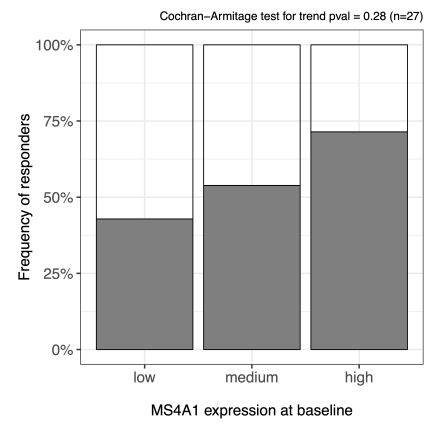

(L)

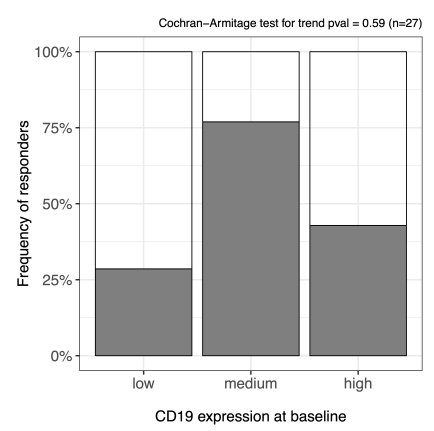

(P)

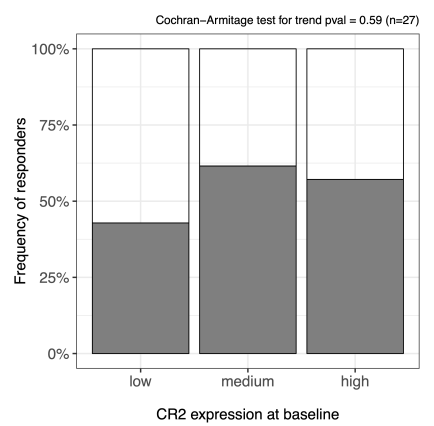

Fig. S9. | Predicting response in ICI treated patients using pre-treatment expression of FRCs or B cells markers.. A-B. Kaplan-Meier curves showing different overall survival and progression-free survival in melanoma patients after commencing treatment with ICI. Patients from (10) were stratified in three groups according to pre-treatment expression of FDCSP. C-D. Association between pre-treatment expression of FDCSP and subsequent ICI response in melanoma patients from (10; Panel C) and in clear cell renal cell carcinoma patients from (12; Panel D). Patients were stratified in three groups according to pre-treatment expression of FDCSP maintaining the same proportions used in panel A and D. E-H. Corresponding results obtained using pre-treatment expression of MS4A1/CD2O. I-L. Corresponding results obtained using pre-treatment expression of CD19. M-P. Corresponding results obtained using pre-treatment expression of CR2. 
bioRxiv preprint doi: https://doi.org/10.1101/2020.02.19.955666; this version posted February $28,2020$. The copyright holder for this preprint

(which was not certified by peer review) is the author/funder, who has granted bioRxiv a license to display the preprint in perpetuity. It is made available under aCC-BY-ND 4.0 International license.

Appendix S3: supplementary tables

Table S2 | Top 50 genes for which pre-treatment expression is associated with subsequent ICI response in melanoma. Genes are ordered by the column score which takes into account both $\mathrm{p}$-value and $\log _{2}(f c)$ : score $=\sqrt{-\log _{10}(\mathrm{p}-\text { value }) *\left|\log _{2}(f c)\right|} * \operatorname{sign}\left(\log _{2}(f c)\right)$. The complete list is provided in a separate spreadsheet file (ICl_resp_baseline.xlsx).

\begin{tabular}{|c|c|c|c|c|c|c|c|c|}
\hline & gene & $\log _{2}(f c)$ & $\log _{2}(f c)$ se & p-value & padj & stat & description & score \\
\hline 1 & CR2 & 2.5 & 0.27 & $3.3 \mathrm{E}-21$ & $4.9 \mathrm{E}-17$ & 9.5 & complement $\mathrm{C} 3 \mathrm{~d}$ receptor 2 & 7.1 \\
\hline 2 & FCER2 & 2.2 & 0.32 & $1.3 \mathrm{E}-13$ & $6.3 \mathrm{E}-10$ & 7.4 & $\mathrm{Fc}$ fragment of IgE receptor II & 5.3 \\
\hline 3 & CLEC17A & 2 & 0.28 & $1.9 \mathrm{E}-14$ & $1.5 \mathrm{E}-10$ & 7.7 & C-type lectin domain containing $17 \mathrm{~A}$ & 5.3 \\
\hline 4 & PAX5 & 2.2 & 0.33 & $8.2 \mathrm{E}-13$ & 3.1E-09 & 7.2 & paired box 5 & 5.1 \\
\hline 5 & FDCSP & 2.2 & 0.36 & $6.7 \mathrm{E}-11$ & 1.7E-07 & 6.5 & follicular dendritic cell secreted protein & 4.7 \\
\hline 6 & CD19 & 1.8 & 0.3 & $1.2 \mathrm{E}-11$ & $3.5 \mathrm{E}-08$ & 6.8 & CD19 molecule & 4.5 \\
\hline 7 & TCL1A & 1.9 & 0.34 & $4.2 \mathrm{E}-10$ & $6.3 \mathrm{E}-07$ & 6.2 & $\mathrm{~T}$ cell leukemia/lymphoma $1 \mathrm{~A}$ & 4.2 \\
\hline 8 & VPREB3 & 1.7 & 0.31 & $1.7 \mathrm{E}-10$ & 2.9E-07 & 6.4 & V-set pre-B cell surrogate light chain 3 & 4.1 \\
\hline 9 & BANK1 & 1.6 & 0.28 & $1 \mathrm{E}-10$ & 2E-07 & 6.5 & B cell scaffold protein with ankyrin repeats 1 & 4 \\
\hline 10 & MS4A1 & 1.7 & 0.32 & $1.2 \mathrm{E}-09$ & $1.6 \mathrm{E}-06$ & 6.1 & membrane spanning 4-domains A1 & 3.9 \\
\hline 11 & TLR10 & 1.4 & 0.24 & 9E-11 & 1.9E-07 & 6.5 & toll like receptor 10 & 3.8 \\
\hline 12 & BLK & 1.3 & 0.25 & $3.1 \mathrm{E}-09$ & $3.6 \mathrm{E}-06$ & 5.9 & BLK proto-oncogene, Src family tyrosine kinase & 3.3 \\
\hline 13 & MUC7 & 1.7 & 0.44 & $6.6 \mathrm{E}-07$ & 0.00038 & 5 & mucin 7 , secreted & 3.3 \\
\hline 14 & PSCA & 1.5 & 0.31 & 4.1E-08 & $3.8 \mathrm{E}-05$ & 5.5 & prostate stem cell antigen & 3.3 \\
\hline 15 & SPIB & 1.3 & 0.26 & 9.9E-09 & 9.9E-06 & 5.7 & Spi-B transcription factor & 3.3 \\
\hline 16 & CYP4F11 & 1.4 & 0.31 & $5.1 \mathrm{E}-08$ & 4.5E-05 & 5.4 & cytochrome P450 family 4 subfamily F member 11 & 3.2 \\
\hline 17 & FAM129C & 1.2 & 0.23 & 5.3E-09 & 5.7E-06 & 5.8 & family with sequence similarity 129 member C & 3.2 \\
\hline 18 & CNR2 & 1.2 & 0.25 & $6.6 \mathrm{E}-08$ & $5.5 \mathrm{E}-05$ & 5.4 & cannabinoid receptor 2 & 2.9 \\
\hline 19 & CUX2 & 1.3 & 0.3 & $3.2 \mathrm{E}-07$ & 0.0002 & 5.1 & cut like homeobox 2 & 2.9 \\
\hline 20 & FCRL1 & 1.3 & 0.33 & $1 \mathrm{E}-06$ & 0.00053 & 4.9 & Fc receptor like 1 & 2.8 \\
\hline 21 & CCR7 & 1.2 & 0.25 & 2E-07 & 0.00014 & 5.2 & C-C motif chemokine receptor 7 & 2.8 \\
\hline 22 & P2RX5 & 1.1 & 0.24 & $2.2 \mathrm{E}-07$ & 0.00015 & 5.2 & purinergic receptor $\mathrm{P} 2 \mathrm{X} 5$ & 2.7 \\
\hline 23 & GPX2 & 1.1 & 0.29 & $3 \mathrm{E}-06$ & 0.0014 & 4.7 & glutathione peroxidase 2 & 2.5 \\
\hline 24 & TSPAN8 & 1.2 & 0.38 & $1.1 \mathrm{E}-05$ & 0.0035 & 4.4 & tetraspanin 8 & 2.5 \\
\hline 25 & TNFRSF13C & 0.98 & 0.22 & 8.7E-07 & 0.00048 & 4.9 & TNF receptor superfamily member $13 \mathrm{C}$ & 2.4 \\
\hline 26 & CCL21 & 1.2 & 0.39 & $1.6 \mathrm{E}-05$ & 0.0048 & 4.3 & $\mathrm{C}-\mathrm{C}$ motif chemokine ligand 21 & 2.4 \\
\hline 27 & ABAT & 0.9 & 0.21 & $1.2 \mathrm{E}-06$ & 0.00061 & 4.9 & 4-aminobutyrate aminotransferase & 2.3 \\
\hline 28 & RGS13 & 1.1 & 0.34 & $1.8 \mathrm{E}-05$ & 0.0051 & 4.3 & regulator of $G$ protein signaling 13 & 2.2 \\
\hline 29 & GP1BA & 0.88 & 0.21 & $2.1 \mathrm{E}-06$ & 0.00096 & 4.7 & glycoprotein Ib platelet subunit alpha & 2.2 \\
\hline 30 & STAP1 & 1 & 0.31 & $1.4 \mathrm{E}-05$ & 0.0044 & 4.3 & signal transducing adaptor family member 1 & 2.2 \\
\hline 31 & CD79A & 1 & 0.37 & 2.7E-05 & 0.0068 & 4.2 & CD79a molecule & 2.2 \\
\hline 32 & SLC27A2 & 1 & 0.32 & $1.8 \mathrm{E}-05$ & 0.0051 & 4.3 & solute carrier family 27 member 2 & 2.2 \\
\hline 33 & $\mathrm{C} 4 \mathrm{~A}$ & 0.88 & 0.23 & 4.9E-06 & 0.002 & 4.6 & complement C4A (Rodgers blood group) & 2.2 \\
\hline 34 & TREML2 & 0.93 & 0.26 & $9.8 \mathrm{E}-06$ & 0.0033 & 4.4 & triggering receptor expressed on myeloid cells like 2 & 2.2 \\
\hline 35 & APOC4-APOC2 & 1.1 & 0.46 & $5.1 \mathrm{E}-05$ & 0.011 & 4.1 & APOC4-APOC2 readthrough (NMD candidate) & 2.2 \\
\hline 36 & DNASE1L3 & 0.96 & 0.3 & $1.8 \mathrm{E}-05$ & 0.0051 & 4.3 & deoxyribonuclease 1 like 3 & 2.1 \\
\hline 37 & LRMP & 0.78 & 0.2 & $5.5 \mathrm{E}-06$ & 0.0021 & 4.5 & lymphoid restricted membrane protein & 2 \\
\hline 38 & AMDHD1 & 0.83 & 0.25 & $1.7 \mathrm{E}-05$ & 0.0051 & 4.3 & amidohydrolase domain containing 1 & 2 \\
\hline 39 & CPS1 & 0.88 & 0.31 & $3.5 \mathrm{E}-05$ & 0.0085 & 4.1 & carbamoyl-phosphate synthase 1 & 2 \\
\hline 40 & PLAC8 & 0.84 & 0.27 & $2.5 \mathrm{E}-05$ & 0.0066 & 4.2 & placenta associated 8 & 2 \\
\hline 41 & CCR6 & 0.96 & 0.46 & $9.7 \mathrm{E}-05$ & 0.017 & 3.9 & C-C motif chemokine receptor 6 & 2 \\
\hline 42 & SELL & 0.8 & 0.25 & $2 \mathrm{E}-05$ & 0.0054 & 4.3 & selectin L & 1.9 \\
\hline 43 & $\mathrm{C} 4 \mathrm{~B}$ & 0.78 & 0.25 & $2.5 \mathrm{E}-05$ & 0.0066 & 4.2 & complement C4B (Chido blood group) & 1.9 \\
\hline 44 & MUC3A & 0.77 & 0.27 & 4.1E-05 & 0.0092 & 4.1 & mucin $3 \mathrm{~A}$, cell surface associated & 1.8 \\
\hline 45 & VIPR1 & 0.78 & 0.32 & 7.4E-05 & 0.014 & 4 & vasoactive intestinal peptide receptor 1 & 1.8 \\
\hline 46 & IGHV1-58 & 0.89 & 0.62 & 0.00026 & 0.035 & 3.7 & immunoglobulin heavy variable $1-58$ & 1.8 \\
\hline 47 & SLC22A1 & 0.79 & 0.37 & 0.00011 & 0.018 & 3.9 & solute carrier family 22 member 1 & 1.8 \\
\hline 48 & CFHR4 & 0.9 & 0.77 & 0.00036 & 0.039 & 3.6 & complement factor $\mathrm{H}$ related 4 & 1.8 \\
\hline 49 & ABCG5 & 0.79 & 0.37 & 0.00012 & 0.019 & 3.9 & ATP binding cassette subfamily $\mathrm{G}$ member 5 & 1.8 \\
\hline 50 & OIT3 & 0.83 & 0.47 & 0.00018 & 0.027 & 3.7 & oncoprotein induced transcript 3 & 1.8 \\
\hline
\end{tabular}


bioRxiv preprint doi: https://doi.org/10.1101/2020.02.19 955666; this version posted February 28,2020 . The copyright holder for this preprint (which was not certified by peer review) is the author/funder, who has granted bioRxiv a license to display the preprint in perpetuity. It is made available under aCC-BY-ND 4.0 International license.

Table S3 | Multiple linear regression analysis of ICI response, including plasma cell markers. expression of $F D C S P$ is significantly associated with ICI response independently of genes expressed in major immune cell types, including Plasma cells. Asterisks indicate the level of statistical significance: *** indicates $p$-value $\leq 0.001$, ** indicates $\mathrm{p}$-value $\leq 0.01,{ }^{*}$ indicates $\mathrm{p}$-value $\leq 0.05$.

\begin{tabular}{|c|c|c|c|c|c|c|c|}
\hline & Cell type & Markers & Estimate & Std. Error & $\mathrm{t}$ value & $\operatorname{Pr}(>|t|)$ & \\
\hline 1 & CD8+ T cells & CD8A, CD8B, TRAC & 0.077 & 0.082 & 0.93 & 0.35 & \\
\hline 2 & CD4+ T cells & CD4, TRAC & 0.049 & 0.110 & 0.45 & 0.65 & \\
\hline 3 & NK cells & GNLY, KLRF1 & -0.074 & 0.092 & -0.80 & 0.42 & \\
\hline 4 & B cells & MS4A1, CD19 & 0.078 & 0.053 & 1.50 & 0.14 & \\
\hline 5 & Macrophages & CD163, MARCO & -0.019 & 0.049 & -0.40 & 0.69 & \\
\hline 6 & Dendritic cells & CD1A, CD1B, CD1E, LILRA4 & -0.059 & 0.075 & -0.78 & 0.44 & \\
\hline 7 & Plasma cells & TNFRSF17, MZB1 & -0.093 & 0.056 & -1.70 & 0.098 & \\
\hline 8 & FDCSP+ cells & FDCSP & 0.067 & 0.027 & 2.50 & 0.014 & * \\
\hline
\end{tabular}

Table S4 Multiple linear regression analysis of ICI response, excluding FDCSP. Expression of B cell markers is significantly associated with ICI response independently of CD8+ T cells and other immune cell types. However, such association becomes statistically non-significant when expression of $F D C S P$ is taken into account in the multiple regression model (Table 1 and Table S3). Asterisks indicate the level of statistical significance: ${ }^{* * *}$ indicates $p$-value $\leq 0.001$, ${ }^{* \star}$ indicates $p$-value $\leq 0.01,{ }^{*}$ indicates $p$-value $\leq 0.05$.

\begin{tabular}{lllrrrrr}
\hline & Cell type & Markers & Estimate & Std. Error & $\mathrm{t}$ value & $\operatorname{Pr}(>|\mathrm{t}|)$ \\
\hline 1 & CD8+ T cells & CD8A, CD8B, TRAC & 0.096 & 0.083 & 1.20 & 0.25 \\
2 & CD4+ T cells & CD4, TRAC & 0.044 & 0.110 & 0.40 & 0.69 \\
3 & NK cells & GNLY, KLRF1 & -0.045 & 0.093 & -0.48 & 0.63 \\
4 & B cells & MS4A1, CD19 & 0.120 & 0.051 & 2.20 & 0.027 & $*$ \\
5 & Macrophages & CD163, MARCO & -0.018 & 0.049 & -0.37 & 0.71 \\
6 & Dendritic cells & CD1A, CD1B, CD1E, LILRA4 & -0.073 & 0.076 & -0.97 & 0.33 \\
7 & Plasma cells & TNFRSF17, MZB1 & -0.110 & 0.056 & -1.90 & 0.064 \\
\hline
\end{tabular}


bioRxiv preprint doi: https://doi.org/10.1101/2020.02.19.955666; this version posted February 28,2020 . The copyright holder for this preprint (which was not certified by peer review) is the author/funder, who has granted bioRxiv a license to display the preprint in perpetuity. It is made available under aCC-BY-ND 4.0 International license.

Table S5 | Top 50 genes up-regulated in FDCSP+ fibroblasts compared to FDCSP- fibroblasts detected by using single-cell RNAseq data. Differential gene expression analysis comparing single-cell transcriptomes of FDCSP+ fibroblasts versus FDCSP-fibroblasts obtained from lung cancer (NSCLC) and melanoma tumours (MEL). The analysis was performed using gene expression data published in $(25,27)$. Results from both datasets were meta-analysed using the RankProduct method (RP; see supplementary methods). The complete list is provided in a separate spreadsheet file (FDCSP_pos_vs_FDCSP_neg_fibroblasts.xIsx).

\begin{tabular}{|c|c|c|c|c|c|c|c|}
\hline & gene & NSCLC_l $\log _{2}(f c)$ & NSCLC_pvalue & MEL_log ${ }_{2}(f c)$ & MEL_pvalue & description & $\mathrm{RP}$ \\
\hline 1 & CCL21 & 0.91 & $2.5 \mathrm{E}-16$ & 12 & $8.5 \mathrm{E}-13$ & C-C motif chemokine ligand 21 & 1.4 \\
\hline 2 & FDCSP & 1.7 & $3.2 \mathrm{E}-127$ & 7.5 & 4.7E-17 & follicular dendritic cell secreted protein & 1.4 \\
\hline 3 & CCL19 & 1.2 & $7.2 \mathrm{E}-11$ & 8.4 & $1.3 \mathrm{E}-08$ & C-C motif chemokine ligand 19 & 3.9 \\
\hline 4 & SLCO2B1 & 0.33 & $6.9 \mathrm{E}-10$ & 2.9 & $2.3 \mathrm{E}-11$ & solute carrier organic anion transporter family member $2 \mathrm{~B} 1$ & 10 \\
\hline 5 & TNFSF13B & 0.71 & 7.5E-09 & 4.2 & $3.5 \mathrm{E}-06$ & TNF superfamily member $13 \mathrm{~b}$ & 11 \\
\hline 6 & CADM3 & 0.49 & $1.3 \mathrm{E}-15$ & 2 & $9.1 \mathrm{E}-09$ & cell adhesion molecule 3 & 12 \\
\hline 7 & $\mathrm{C} 3$ & 1.8 & 7.3E-06 & 4.3 & 0.01 & complement $\mathrm{C} 3$ & 18 \\
\hline 8 & C7 & 0.83 & 0.00043 & 4.7 & 0.00025 & complement $\mathrm{C} 7$ & 19 \\
\hline 9 & $\mathrm{CP}$ & 0.22 & 9E-07 & 3.4 & $2.2 \mathrm{E}-12$ & ceruloplasmin & 20 \\
\hline 10 & UBD & 0.06 & $2.4 \mathrm{E}-10$ & 7 & $6.2 \mathrm{E}-13$ & ubiquitin D & 25 \\
\hline 11 & ADH1B & 0.48 & 0.0069 & 4.6 & $2.6 \mathrm{E}-06$ & alcohol dehydrogenase 1B (class I), beta polypeptide & 32 \\
\hline 12 & PAPLN & 0.51 & 3.3E-09 & 2 & 0.016 & papilin, proteoglycan like sulfated glycoprotein & 39 \\
\hline 13 & CXCL13 & 0.23 & $3.4 \mathrm{E}-06$ & 2.4 & 2.3E-07 & $\mathrm{C}-\mathrm{X}-\mathrm{C}$ motif chemokine ligand 13 & 41 \\
\hline 14 & VCAM1 & 0.56 & 0.0023 & 4 & 0.00055 & vascular cell adhesion molecule 1 & 42 \\
\hline 15 & C10orf10 & 0.58 & 0.068 & 6.3 & 8.3E-05 & & 42 \\
\hline 16 & CD74 & 0.37 & 0.036 & 6.5 & $7.5 \mathrm{E}-05$ & CD74 molecule & 45 \\
\hline 17 & RBP5 & 0.18 & $4 \mathrm{E}-08$ & 3.3 & 0.00011 & retinol binding protein 5 & 46 \\
\hline 18 & CXCL14 & 0.77 & 0.0049 & 4.4 & 0.023 & $\mathrm{C}-\mathrm{X}-\mathrm{C}$ motif chemokine ligand 14 & 54 \\
\hline 19 & PTGDS & 0.25 & 0.22 & 8.9 & $2.8 \mathrm{E}-06$ & prostaglandin D2 synthase & 60 \\
\hline 20 & DAAM1 & 0.38 & 0.0072 & 2.7 & 0.0001 & dishevelled associated activator of morphogenesis 1 & 70 \\
\hline 21 & ZFP36L2 & 0.68 & 0.0014 & 2.1 & 0.014 & ZFP36 ring finger protein like 2 & 71 \\
\hline 22 & NFIB & 0.66 & 0.0018 & 1.9 & 0.0098 & nuclear factor I B & 73 \\
\hline 23 & CSF2RB & 0.23 & $5.2 \mathrm{E}-06$ & 1.7 & 3.2E-05 & colony stimulating factor 2 receptor beta common subunit & 74 \\
\hline 24 & RAMP3 & 0.02 & 0.043 & 6.4 & 4.7E-17 & receptor activity modifying protein 3 & 76 \\
\hline 25 & CSMD1 & 0.2 & 0.0031 & 1.4 & $1.6 \mathrm{E}-10$ & CUB and Sushi multiple domains 1 & 79 \\
\hline 26 & IL6ST & 0.54 & 0.022 & 2.6 & 0.001 & interleukin 6 signal transducer & 86 \\
\hline 27 & SLC22A3 & 0.04 & 0.0034 & 5.1 & 2.7E-08 & solute carrier family 22 member 3 & 88 \\
\hline 28 & NFKBIA & 0.45 & 0.1 & 4.7 & 0.0017 & NFKB inhibitor alpha & 88 \\
\hline 29 & $\mathrm{C} 1 \mathrm{R}$ & 0.89 & 0.0022 & 2.1 & 0.27 & complement $\mathrm{C} 1 \mathrm{r}$ & 103 \\
\hline 30 & BIRC3 & 0.28 & 0.025 & 1.4 & 4.1E-08 & baculoviral IAP repeat containing 3 & 105 \\
\hline 31 & SERPINB9 & 0.25 & 0.0011 & 3.6 & 0.016 & serpin family B member 9 & 109 \\
\hline 32 & CTSH & 0.08 & 0.08 & 6.4 & $3.6 \mathrm{E}-05$ & cathepsin $\mathrm{H}$ & 110 \\
\hline 33 & IGFBP7 & 1.1 & 0.0097 & 1.6 & 0.18 & insulin like growth factor binding protein 7 & 112 \\
\hline 34 & CTSS & 0.39 & $5.5 \mathrm{E}-05$ & 1.7 & 0.055 & cathepsin S & 114 \\
\hline 35 & CLK1 & 0.57 & 0.0013 & 1.7 & 0.068 & CDC like kinase 1 & 120 \\
\hline 36 & ZBTB16 & 0.17 & 0.04 & 2.8 & $9.7 \mathrm{E}-06$ & zinc finger and BTB domain containing 16 & 120 \\
\hline 37 & RPL13 & 0.98 & 0.00015 & 0.35 & 0.24 & ribosomal protein L13 & 124 \\
\hline 38 & LPAR1 & 0.31 & 0.00015 & 2.1 & 0.041 & lysophosphatidic acid receptor 1 & 129 \\
\hline 39 & SOD2 & 0.62 & 0.12 & 3.5 & 0.014 & superoxide dismutase 2 & 130 \\
\hline 40 & KLRK1 & 0.1 & $5.9 \mathrm{E}-10$ & 0.97 & 0.00031 & killer cell lectin like receptor $\mathrm{K} 1$ & 135 \\
\hline 41 & XIST & 0.37 & 0.0089 & 2.1 & 0.013 & $\mathrm{X}$ inactive specific transcript & 136 \\
\hline 42 & IL33 & 0.29 & $1.3 \mathrm{E}-05$ & 1.4 & 0.041 & interleukin 33 & 138 \\
\hline 43 & IER3 & 0.51 & 0.032 & 2.5 & 0.027 & immediate early response 3 & 139 \\
\hline 44 & HLA-DRB1 & 0.36 & $2.5 \mathrm{E}-06$ & 1.3 & 0.21 & major histocompatibility complex, class II, DR beta 1 & 139 \\
\hline 45 & CYP1B1 & 0.66 & 0.00034 & 1 & 0.23 & cytochrome P450 family 1 subfamily B member 1 & 140 \\
\hline 46 & ARHGAP15 & 0.05 & 0.37 & 4 & $5.4 \mathrm{E}-10$ & Rho GTPase activating protein 15 & 144 \\
\hline 47 & JUN & 0.92 & 0.026 & 1.9 & 0.17 & Jun proto-oncogene, AP-1 transcription factor subunit & 148 \\
\hline 48 & FKBP1A & 0.36 & 0.05 & 2.1 & 0.0016 & FKBP prolyl isomerase 1A & 152 \\
\hline 49 & CLU & 0.21 & 0.29 & 5.5 & 0.001 & clusterin & 154 \\
\hline 50 & IRF8 & 0.08 & 0.019 & 2.4 & 8.4E-07 & interferon regulatory factor 8 & 154 \\
\hline 51 & CXCL12 & 0.26 & 0.12 & 3.6 & 0.0021 & $\mathrm{C}-\mathrm{X}-\mathrm{C}$ motif chemokine ligand 12 & 158 \\
\hline 52 & C1S & 0.58 & 0.068 & 2.7 & 0.054 & complement $\mathrm{C} 1 \mathrm{~s}$ & 158 \\
\hline 53 & TMEM176B & 0.28 & 0.25 & 4.2 & 0.0017 & transmembrane protein $176 \mathrm{~B}$ & 161 \\
\hline 54 & NAP1L1 & 0.69 & 0.0041 & 1.2 & 0.13 & nucleosome assembly protein 1 like 1 & 164 \\
\hline 55 & ABHD2 & 0.6 & $2.3 \mathrm{E}-05$ & 0.43 & 0.37 & abhydrolase domain containing 2 & 168 \\
\hline 56 & KEL & 0 & 0.88 & 3.3 & $9.4 \mathrm{E}-14$ & Kell metallo-endopeptidase (Kell blood group) & 183 \\
\hline 57 & LAMA3 & 0.05 & 0.0031 & 2.1 & $1.4 \mathrm{E}-06$ & laminin subunit alpha 3 & 189 \\
\hline 58 & STRA6 & 0.08 & 0.038 & 1.6 & $6.2 \mathrm{E}-08$ & stimulated by retinoic acid 6 & 195 \\
\hline 59 & RBP1 & 0.07 & 0.25 & 4.6 & 0.00017 & retinol binding protein 1 & 196 \\
\hline 60 & $\mathrm{ABCC} 3$ & 0.04 & 0.14 & 3.2 & $5.2 \mathrm{E}-07$ & ATP binding cassette subfamily $\mathrm{C}$ member 3 & 198 \\
\hline
\end{tabular}


bioRxiv preprint doi: https://doi.org/10.1101/2020.02.19.955666; this version posted February 28,2020 . The copyright holder for this preprint (which was not certified by peer review) is the author/funder, who has granted bioRxiv a license to display the preprint in perpetuity. It is made available under aCC-BY-ND 4.0 International license.

Table S6 | Top 50 genes down-regulated in FDCSP+ fibroblasts compared to FDCSP- fibroblasts detected by using single-cell RNAseq data. Differential gene expression analysis comparing single-cell transcriptomes of FDCSP+ fibroblasts versus FDCSP-fibroblasts obtained from lung cancer (NSCLC) and melanoma tumours (MEL). The analysis was performed using gene expression data published in (25, 27). Results from both datasets were meta-analysed using the RankProduct method (RP; see supplementary methods). The complete list is provided in a separate spreadsheet file (FDCSP_pos_vs_FDCSP_neg_fibroblasts.xlsx).

\begin{tabular}{|c|c|c|c|c|c|c|c|}
\hline & gene & NSCLC_ $\log _{2}(f c)$ & NSCLC_pvalue & $\mathrm{MEL}_{2} \log _{2}(f c)$ & MEL_pvalue & description & RP \\
\hline 1 & FN1 & -1.1 & 0.0024 & -5.8 & 0.001 & fibronectin 1 & 14226 \\
\hline 2 & CTHRC1 & -0.79 & 0.0042 & -4.9 & 0.0032 & collagen triple helix repeat containing 1 & 14222 \\
\hline 3 & TIMP3 & -0.87 & 0.019 & -3.2 & 0.0017 & TIMP metallopeptidase inhibitor 3 & 14218 \\
\hline 4 & COL1A2 & -1.1 & 0.011 & -3.1 & 0.0032 & collagen type I alpha 2 chain & 14212 \\
\hline 5 & COL1A1 & -1.6 & 0.011 & -3 & 0.0056 & collagen type I alpha 1 chain & 14210 \\
\hline 6 & COL5A1 & -0.87 & 0.0061 & -2.9 & 0.0053 & collagen type $\mathrm{V}$ alpha 1 chain & 14206 \\
\hline 7 & ARF4 & -0.43 & 0.0095 & -3.2 & 0.0077 & ADP ribosylation factor 4 & 14204 \\
\hline 8 & LGALS1 & -0.46 & 0.13 & -5.8 & 0.00057 & galectin 1 & 14203 \\
\hline 9 & COL5A2 & -0.81 & 0.019 & -2.9 & 0.0073 & collagen type $\mathrm{V}$ alpha 2 chain & 14199 \\
\hline 10 & PRSS23 & -0.34 & 0.084 & -3.8 & 0.0044 & serine protease 23 & 14194 \\
\hline 11 & POSTN & -0.6 & 0.11 & -3.6 & 0.021 & periostin & 14187 \\
\hline 12 & MMP2 & -0.48 & 0.14 & -3.1 & 0.011 & matrix metallopeptidase 2 & 14180 \\
\hline 13 & COL8A1 & -0.35 & 0.12 & -3.3 & 0.0094 & collagen type VIII alpha 1 chain & 14176 \\
\hline 14 & VCAN & -0.42 & 0.12 & -3.1 & 0.011 & versican & 14176 \\
\hline 15 & SPON2 & -0.32 & 0.038 & -2.8 & 0.011 & spondin 2 & 14174 \\
\hline 16 & CYB5R3 & -0.38 & 0.024 & -2.5 & 0.014 & cytochrome b5 reductase 3 & 14161 \\
\hline 17 & ACTB & -0.4 & 0.078 & -2.2 & 0.0053 & actin beta & 14160 \\
\hline 18 & ITGB5 & -0.37 & 0.0093 & -2.2 & 0.0094 & integrin subunit beta 5 & 14158 \\
\hline 19 & CAV1 & -0.2 & 0.15 & -3.9 & 0.0032 & caveolin 1 & 14154 \\
\hline 20 & ITGA11 & -0.3 & 0.035 & -2.4 & 0.0094 & integrin subunit alpha 11 & 14153 \\
\hline 21 & FBN1 & -0.53 & 0.012 & -2.4 & 0.015 & fibrillin 1 & 14152 \\
\hline 22 & CHPF & -0.17 & 0.067 & -2.7 & 0.0044 & chondroitin polymerizing factor & 14151 \\
\hline 23 & FKBP9 & -0.27 & 0.087 & -2.5 & 0.006 & FKBP prolyl isomerase 9 & 14150 \\
\hline 24 & ECM1 & -0.14 & 0.089 & -3.4 & 0.0027 & extracellular matrix protein 1 & 14145 \\
\hline 25 & ANXA5 & -0.38 & 0.055 & -2.1 & 0.0084 & annexin A5 & 14145 \\
\hline 26 & LOX & -0.22 & 0.045 & -3 & 0.023 & lysyl oxidase & 14137 \\
\hline 27 & RAB31 & -0.45 & 0.033 & -2.1 & 0.015 & RAB31, member RAS oncogene family & 14122 \\
\hline 28 & ITGB1 & -0.69 & 0.017 & -2.3 & 0.024 & integrin subunit beta 1 & 14122 \\
\hline 29 & CNN2 & -0.52 & 0.0089 & -2 & 0.014 & calponin 2 & 14116 \\
\hline 30 & TPM1 & -0.29 & 0.12 & -2.7 & 0.027 & tropomyosin 1 & 14108 \\
\hline 31 & CTGF & -0.32 & 0.16 & -3.2 & 0.05 & & 14105 \\
\hline 32 & INHBA & -0.41 & 0.097 & -2.3 & 0.024 & inhibin subunit beta $\mathrm{A}$ & 14102 \\
\hline 33 & S100A11 & -0.23 & 0.34 & -4.3 & 0.001 & S100 calcium binding protein A11 & 14101 \\
\hline 34 & GPNMB & -0.14 & 0.16 & -3.4 & 0.0032 & glycoprotein nmb & 14100 \\
\hline 35 & PXDN & -0.4 & 0.051 & -2 & 0.016 & peroxidasin & 14099 \\
\hline 36 & THBS2 & -0.47 & 0.091 & -2.6 & 0.044 & thrombospondin 2 & 14098 \\
\hline 37 & SFRP2 & -0.29 & 0.36 & -4.1 & 0.043 & secreted frizzled related protein 2 & 14096 \\
\hline 38 & CAPN2 & -0.15 & 0.076 & -2.6 & 0.021 & calpain 2 & 14091 \\
\hline 39 & EFEMP2 & -0.12 & 0.13 & -3.8 & 0.0046 & EGF containing fibulin extracellular matrix protein 2 & 14085 \\
\hline 40 & TPM4 & -0.42 & 0.18 & -2 & 0.014 & tropomyosin 4 & 14083 \\
\hline 41 & COPS8 & -0.18 & 0.19 & -2.4 & 0.014 & COP9 signalosome subunit 8 & 14071 \\
\hline 42 & FHL2 & -0.12 & 0.15 & -2.8 & 0.0094 & four and a half LIM domains 2 & 14065 \\
\hline 43 & CAPZB & -0.29 & 0.19 & -1.9 & 0.013 & capping actin protein of muscle Z-line subunit beta & 14065 \\
\hline 44 & NOP10 & -0.12 & 0.11 & -2.7 & 0.019 & NOP10 ribonucleoprotein & 14062 \\
\hline 45 & CERCAM & -0.13 & 0.22 & -3.5 & 0.0044 & cerebral endothelial cell adhesion molecule & 14061 \\
\hline 46 & FSCN1 & -0.22 & 0.12 & -1.6 & 0.0051 & fascin actin-bundling protein 1 & 14057 \\
\hline 47 & NDUFB10 & -0.12 & 0.12 & -2.6 & 0.014 & NADH:ubiquinone oxidoreductase subunit B10 & 14054 \\
\hline 48 & HSPG2 & -0.23 & 0.065 & -1.6 & 0.0098 & heparan sulfate proteoglycan 2 & 14053 \\
\hline 49 & SULF1 & -0.48 & 0.04 & -2.2 & 0.052 & sulfatase 1 & 14044 \\
\hline 50 & PLAT & -0.26 & 0.037 & -1.9 & 0.027 & plasminogen activator, tissue type & 14042 \\
\hline 51 & SPARC & -1.1 & 0.0011 & -1.8 & 0.033 & secreted protein acidic and cysteine rich & 14036 \\
\hline 52 & CD55 & -0.15 & 0.11 & -2.1 & 0.022 & CD55 molecule (Cromer blood group) & 14034 \\
\hline 53 & CALM2 & -0.25 & 0.28 & -2.5 & 0.044 & calmodulin 2 & 14020 \\
\hline 54 & VDAC2 & -0.14 & 0.15 & -2.6 & 0.032 & voltage dependent anion channel 2 & 14019 \\
\hline 55 & REXO2 & -0.21 & 0.15 & -2 & 0.029 & RNA exonuclease 2 & 14019 \\
\hline 56 & HTRA1 & -0.15 & 0.31 & -2.9 & 0.0044 & HtrA serine peptidase 1 & 14010 \\
\hline 57 & MFAP2 & -0.13 & 0.22 & -3.1 & 0.016 & microfibril associated protein 2 & 14010 \\
\hline 58 & MFAP5 & -0.12 & 0.22 & -3.8 & 0.021 & microfibril associated protein 5 & 14009 \\
\hline 59 & GSTP1 & -0.19 & 0.27 & -2.3 & 0.024 & glutathione $S$-transferase pi 1 & 14004 \\
\hline 60 & ASPN & -0.33 & 0.076 & -2.5 & 0.097 & asporin & 14002 \\
\hline
\end{tabular}




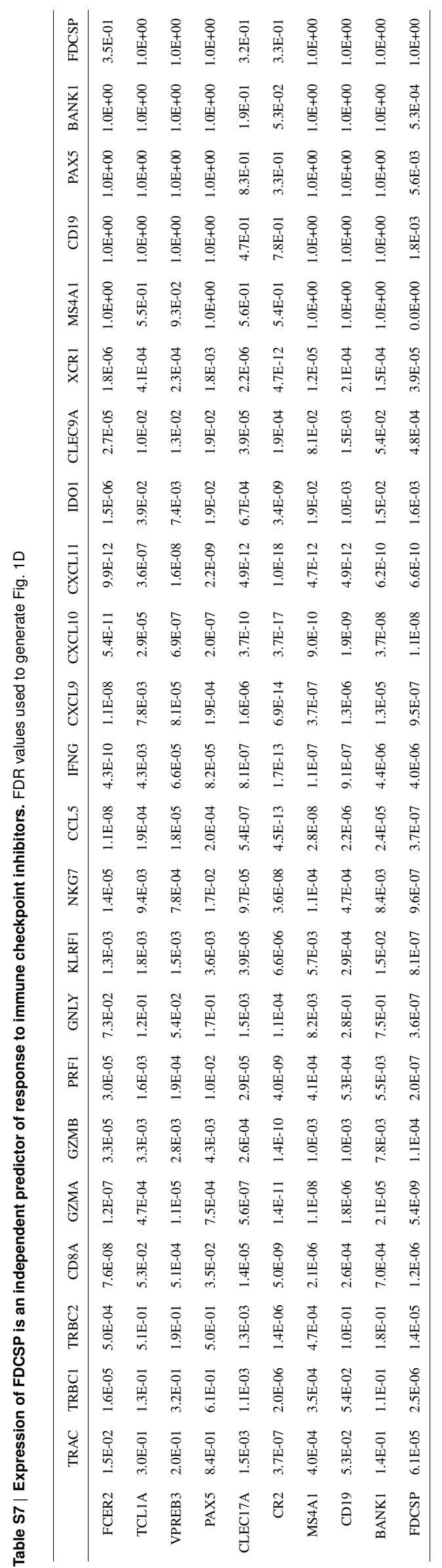

